OPEN ACCESS

Edited by:

Marc S. Horwitz,

University of British Columbia,

Canada

Reviewed by:

David H. Wagner,

University of Colorado Denver,

United States

Margaret A. Morris,

Eastern Virginia Medical School,

United States

*Correspondence:

Clayton E. Mathews

clayton.mathews@pathology.ufl.edu

Specialty section:

This article was submitted to Diabetes,

a section of the journal

Frontiers in Endocrinology

Received: 29 June 2017

Accepted: 25 August 2017

Published: 14 September 2017

Citation:

Newby BN and Mathews CE (2017)

Type I Interferon Is a Catastrophic

Feature of the Diabetic Islet

Microenvironment.

Front. Endocrinol. 8:232.

doi: 10.3389/fendo.2017.00232

\section{Type I Interferon Is a Catastrophic Feature of the Diabetic Islet Microenvironment}

\author{
Brittney N. Newby and Clayton E. Mathews* \\ Department of Pathology, Immunology and Laboratory Medicine, University of Florida, Gainesville, FL, United States
}

A detailed understanding of the molecular pathways and cellular interactions that result in islet beta cell ( $\beta$ cell) destruction is essential for the development and implementation of effective therapies for prevention or reversal of type 1 diabetes (T1D). However, events that define the pathogenesis of human T1D have remained elusive. This gap in our knowledge results from the complex interaction between genetics, the immune system, and environmental factors that precipitate T1D in humans. A link between genetics, the immune system, and environmental factors are type 1 interferons (T1-IFNs). These cytokines are well known for inducing antiviral factors that limit infection by regulating innate and adaptive immune responses. Further, several T1D genetic risk loci are within genes that link innate and adaptive immune cell responses to T1-IFN. An additional clue that links T1-IFN to T1D is that these cytokines are a known constituent of the autoinflammatory milieu within the pancreas of patients with T1D. The presence of IFN $\alpha / \beta$ is correlated with characteristic MHC class I (MHC-I) hyperexpression found in the islets of patients with T1D, suggesting that T1-IFNs modulate the cross-talk between autoreactive cytotoxic $\mathrm{CD} 8^{+} \mathrm{T}$ lymphocytes and insulin-producing pancreatic $\beta$ cells. Here, we review the evidence supporting the diabetogenic potential of T1-IFN in the islet microenvironment.

\section{Keywords: type 1 diabetes, type 1 interferons, humans, CD8 $8^{+}$cell, beta cells}

\section{INTRODUCTION}

Type 1 diabetes (T1D) results from an autoimmune-mediated attack that specifically targets insulin (INS)-secreting pancreatic beta ( $\beta$ ) cells. Through the interactions of $\beta$ cell antigen-specific T cell receptors (TCR) with MHC-peptide complexes, $\beta$ cells are destroyed leading to aberrant glucose homeostasis and persistent hyperglycemia. Critical to T1D pathogenesis is the targeted destruction of pancreatic $\beta$ cells mass by autoreactive cytotoxic $\mathrm{CD} 8^{+} \mathrm{T}$ lymphocytes (CTLs) (1-6). Although responses in T1D are directed toward autoantigens, the activation of the $\beta$ cell specific CTLs is expected to be similar to activation of $\mathrm{CD} 8^{+} \mathrm{T}$ cells observed during a typical response to infectious agents. Following activation, autoreactive CTLs clonally expand, home into the pancreatic islets, and survey the surface of $\beta$ cells for antigen presented in the context of MHC class I (MHC-I). Recognition of the specific cognate peptide- human leukocyte antigen (HLA) class I complex results in the induction of TCR signaling, formation of the immunological synapse, and targeted destruction of $\beta$ cells. While the immune system plays a significant role in perpetuating disease pathology, a large body of literature supports the notion that development of T1D is dependent upon a complex network of determinants including those of genetic and 
environmental etiologies (7-15). Tissue microenvironments influence immune responses in models of tumor biology and infectious disease. However, this notion remains largely been unexplored in the target tissues of autoimmune diabetes.

Type 1 interferons (T1-IFNs), classically known for interfering with viral infection, have been implicated in the early stages of T1D autoimmunity (16-21). Transcriptome analysis reveals a T1-IFN signature in the peripheral blood of patients prior to the development of autoantibodies $(16,17)$. Additionally, these cytokines have been identified as being expressed in the pancreata of deceased tissue/organ donors with T1D versus non-diabetic donors $(18,19,21)$. GWAS studies reveal several T1D-associated genes that are involved in the production, signaling, and regulation of the T1-IFN pathway $(12,22)$. Moreover, induction of $\mathrm{T} 1 \mathrm{D}$ has been reported in patients receiving T1-IFN therapy for various conditions including hepatitis C, multiple sclerosis, and hairy cell leukemia (23-30) supporting the idea that these cytokines may actively exacerbate T1D progression. Despite the growing evidence for the role of T1-IFNs in T1D, little is known about how these cytokines contribute to the inflammatory environment of the human autoimmune diabetic islet $(16,17,31-36)$. This review will consider the current paradigms in the natural history of T1D as well as T1-IFN action while summarizing the published literature regarding a role for T1-IFNs in T1D pathogenesis. Additionally, we highlight the exciting new avenues of research suggesting that T1-IFNs may be a catastrophic feature within the diabetic microenvironment.

\section{SETTING THE STAGE FOR AUTOIMMUNITY: ROLE OF GENETIC SUSCEPTIBILITY}

Genetic predisposition constitutes a primary risk factor for the initiation of $\beta$ cell autoimmunity and can be attributed to the complex interplay of more than 50 genetic loci that may impact immune function, INS expression, and $\beta$ cell function $(11,37,38)$. Identified as the first genetic locus associated with T1D in the 1970 s, the HLA region on chromosome 6p21 confers approximately $50 \%$ of the genetic risk for disease development (39). This region, also referred to as (it) IDDM1 (it), is highly polymorphic, containing over 200 identified genes that can be categorized as class I, II, or III genes that play an important role in antigen presentation as well as regulation of this process. Particularly, class I and II genes encode the classical HLA cell surface proteins that are involved in presenting antigen to CD8+ and CD4+ lymphocytes, respectively. In fact, the strongest association is found in patients harboring the specific HLA class II haplotypes, DR3-DQ2 $\left(\mathrm{DRB}^{\star} 301-\mathrm{DQB}^{\star} 201\right)$ and DR4-DQ8 (DRB ${ }^{\star} 401-$ $\left.\mathrm{DQA}^{*} 301-\mathrm{DQB}^{\star} 302\right)$ with the highest risk seen in DR3/DR4 compound heterozygotes $(40,41)$. Conversely, strong protection from T1D is observed in individuals with the $\mathrm{DQB}^{\star} 602$ allele, which is reported in less than $1 \%$ of patients with T1D $(42,43)$. Comparison of high- and low-risk DQ alleles in humans and mouse models reveal key differences in peptide binding, as predisposing alleles contain a substitution of non-charged amino acids (alanine, valine, or serine) for aspartate at position
57, which destabilizes binding of antigenic epitopes (44-46). While most studies assessing HLA risk haplotypes have been carried out in Caucasian individuals, recent efforts have begun to characterize HLA susceptibility in other ethnic groups. For example, HLA genotyping in African American patients found that the African-specific DR9 (DRB1 ${ }^{\star} 09: 01-\mathrm{DQA} 1^{\star} 03: 01$ DQB $\left.1^{\star} 02: 01 \mathrm{~g}\right)$ haplotype in combination with DR4 mimics risk for T1D seen in patients with DR3/DR4 heterozygosity in European populations. Alternatively, the African-specific "DR3" haplotype (DRB1*03:02-DQA1*04:01-DQB1*04:02) confers significant protection (47). Future studies in this area should be geared toward understanding HLA risk haplotypes in individuals of diverse ethnic backgrounds. Although not as widely studied, HLA class I alleles, HLA A $A^{\star} 24$ and HLA B ${ }^{\star 39}$, appear to be associated with increased susceptibility for T1D, decreased age of onset, and fulminant $\beta$ cell destruction (48-50).

Numerous additional loci outside of the HLA region summate the remaining genetic risk for diabetes development, although the individual odds ratios conferred by these regions are modest $(11,12)$. Several of these genes are thought to influence tolerance mechanisms facilitating the escape of autoreactive $\mathrm{T}$ cells into the periphery. For instance, variants within the INS gene are known to modulate thymic INS expression, which comprises about $10 \%$ of the genetic risk for T1D and carry an odds ratio of 2.2 (51-53). Extensive mapping of this region associates variable number of tandem repeats in the $5^{\prime}$ promoter of INS with diabetes risk (53-55). Shorter class I alleles [23-63 repeats] predispose for diabetes, while longer class III alleles [140-210 repeats] are protective (55). The number of tandem repetitions determines INS transcription in the thymus through interactions with the autoimmune regulator, AIRE, which is essential for appropriate $\mathrm{T}$ cell education and provides strong evidence that central tolerance to INS, the primary autoantigen in T1D, is impaired in patients who harbor this risk variant (56).

Protein tyrosine phosphatase non-receptor type 22 (PTPN22) is another well-known example, as this locus confers the third highest genetic association for T1D and is also known to be a regulator of signaling in a variety of immune cell types including lymphocytes, monocytes, dendritic cells (DCs), and neutrophils (57). Case-control and association studies show that this coding variant causes a non-synonymous substitution from an arginine to a tryptophan (R620W) located within the protein-binding domain of PTPN22. Biochemical studies in lymphocytes demonstrate the PTPN22*W620 allele behaves as a gain-of-function mutant with dampened TCR signaling (58). In contrast, the same variant in myeloid derived cell types is highly controversial with some models demonstrating hyperresponsive DC phenotypes with increased $\mathrm{T}$ cell activation while others exhibit reduced function and selective impairment of T1-IFN responses following TLR stimulation $(59,60)$. How might seemingly paradoxical functions be contributing to onset of T1D? On one hand, diminished TCR signaling by the risk variant could impair central and peripheral $\mathrm{T}$ cell tolerance, while reduced T1-IFN production by TLRs may hinder effective clearance of $\beta$-cell tropic viruses triggering self-reactivity (61). Studies remain ongoing to determine the full gamut of functional consequences induced by this variant. 
Like PTPN22, many T1D-associated genes play multiple roles in immune sensing and signaling especially in response to environmental ques, which supports the hypothesis that genetic risk coupled to permissive environmental determinants collectively contribute to diabetes progression. Diabetogenic viruses signify a highly postulated candidate for initiation and potentiation of islet autoimmunity. Critical for the innate immune response to viral infection are T1-IFNs. Several identified genetic loci for T1D also have prominent roles in the induction and signaling of this pathway, including IFIH1 (rs1990760), TYK2 (rs2304256), and STAT4 (rs7574865) (62-64). TYK2 is a tyrosine kinase involved in proximal TI-IFN signal transduction as well as regulation of IFNAR1 surface expression (65-67). Similarly, STAT4 is a key mediator of T1-IFN signaling essential for the generation of Th1 responses, which contribute to the $\mathrm{T}$ cell-mediated pathology observed in diabetes $(68,69)$. Also associated with several other autoimmune disorders, protective variants for each of these genes is associated with reduced T1-IFN signaling $(67,70)$. IFIH1 encodes the protein MDA5, a cytoplasmic sensor of viral double-stranded RNA. The non-synonymous SNP found in IFIH1 results in alanine to threonine amino acid substitution at position 946 (A946T) and may diminish ATPase activity of MDA 5 activity leading to deranged constitutive provocation of T1-IFN as well as blunted viral sensing (62, 71, 72). Compelling evidence in primary human islets reveals that presence of the homozygous risk allele decreases the autonomous innate response to Coxsackievirus B3 (73). Collectively, these data suggest that the A946T risk variant in IFIH1 may act as a double-edged sword, predisposing $\beta$ cells to persistent enteroviral infection while concurrently promoting deleterious T1-IFN production in and around the islet microenvironment.

\section{EVOLUTION OF ISLET DESTRUCTION IN HUMAN DIABETES}

Human $\beta$ cells act as quintessential metabolic sensors working to integrate environmental cues for rapid and efficient glycemic control (74). Reports of decreased C-peptide responses and reduced glucose tolerance in autoantibody positive individuals suggest that ongoing inflammation precipitates the deterioration of $\beta$ cell function prior to diabetes onset (75-77). Additionally, $\beta$ cells are also widely believed to be active participants in promoting a diabetogenic islet microenvironment. For example, MHC-I is known to be hyperexpressed within the islets of T1D patients, suggesting that $\beta$ cells may be more visible to infiltrating CTL $(1,20,21,78)$. Increasing data insinuates that signals arising from the islet microenvironment, such as T1-IFNs, could trigger such disease promoting adaptations. Additionally, active inflammatory signals within the islet microenvironment prompt substantial variation in the $\beta$ cell transcriptome and proteome as well as augmenting the capacity for cytokine and chemokine production by islet or $\beta$ cells (79).

The conceptual model proposed by George Eisenbarth for the natural history of T1D has shaped theories regarding the evolution of T1D pathogenesis $(80,81)$. Many facets of this paradigm have been tested and updated over the past 3 decades.
The amalgamation of genetic pre-disposition and initiating environmental triggers create the framework for models that describe the insurgence of $\beta$ cell autoimmunity. Though the nature of the instigating insult is not completely understood, once initiated, active immune-onslaught can be indicated by the presence of autoantibodies and histological detection of the pathognomonic lesion termed insulitis (82). Found in or around the islets, insulitis is a heterogeneous inflammatory infiltrate comprised of $\mathrm{T}$ lymphocytes, B lymphocytes, macrophages, and DCs, however $\mathrm{CD}^{+} \mathrm{T}$ cells form the primary constituent $[(1,2,83)$ and Figure 1A $]$. First noted by German pathologist Martin Schmidt in the early 1900s, this lesion was not considered a prominent feature of T1D until the landmark paper by Willy Gepts in 1965 where the presence of insulitic lesions were observed in 15/22 recent onset T1D cases $(82,84,85)$. Further evaluation of these samples using immunohistochemical techniques and additional data from subsequent studies revealed that inflammation was primarily observed in islets with INS immunoreactivity. Further, in cases with long-standing disease, many islets appear to be devoid of INS containing $\beta$ cells without active insulitis, alluding to the role of these cells as the inciting antigen in $\mathrm{T} 1 \mathrm{D}(1,2,20,82,86-88)$.

Until recently, efforts aimed at characterizing the nature, composition, and frequency of insulitis have been challenging. This is due to the anatomical inaccessibility of the pancreas for direct study in living subjects as well as a dearth of well-preserved human cadaveric tissues for analysis $(84,89)$. The inception of the Network for Pancreatic Organ Donors with Diabetes (nPOD) has dramatically advanced our understanding of $\beta$ cell/Islet autoimmunity (89-92). Moreover, studies of human pancreata have allowed for the emergence of new paradigms in T1D, including the current consensus definition of insulitis, defined as the presence of more than 15 peri- or intrainsulitic $\mathrm{CD} 45^{+}$cells within a minimum of three islets (93). The most comprehensive screening and characterization of insulitis to date was recently described using the nPOD collection where a total of 159 pancreata were screened (61 controls, 18 autoantibody positive cases without a diagnosis of T1D, and 80 T1D cases) (88). Investigators presented confirmatory findings that insulitis is present most frequently in recent-onset patients within INScontaining islets and inversely correlates with disease duration. The presence of adaptive-immune infiltration into the islets of individuals with autoantibodies is a rare event, observed only in individuals with multiple antibodies (94). Additionally, patients with T1D display tremendous heterogeneity in terms nature, distribution, and severity of insulitis in addition to the amount of residual $\beta$ mass present following diagnosis $(88,95)$.

A critical cell-to-cell interaction during the development of T1D occurs when $\beta$ cells and islet-antigen specific CTLs come into contact. Strong evidence has supported a crucial role for $\mathrm{CD}^{+}$ T cells in T1D. First reported by Bottazzo in 1985, histological characterization of pancreas sections from T1D cases demonstrated that CTL are the most abundant immune cell type found in human insulitis [(20) and Figure 1A]. Additional studies have confirmed that $\mathrm{CD}^{+} \mathrm{T}$ cells have a prominent role in T1D as well as recurrent T1D that occurs after transplantation of islets, pancreas (pancreas alone, or SPK recipients) into patients with T1D. 

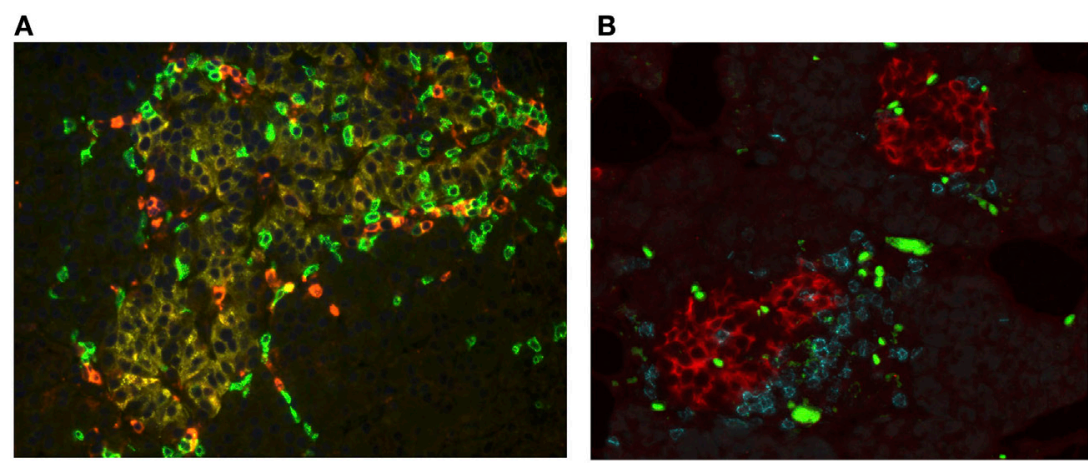

FIGURE 1 | CD8 T cells are the major leukocyte component of the insulitis lesion in type 1 diabetes (T1D) as well as recurrent disease. Pancreatic sections [courtesy of Network for Pancreatic Organ Donors with Diabetes (nPOD)] were examine histologically for the presence of islet invading immune cells. (A) Section taken from a pancreas organ donor with T1D (nPOD case 6052). The tissue section was immunofluorescently stained for glucagon (yellow) to identify the islet, CD4 T lymphocytes (red), and CD8 T lymphocytes (green). Within this islet cytotoxic CD8 ${ }^{+} \mathrm{T}$ lymphocytes (CTLs) are the predominant T cell type observed. Image courtesy of Martha Campbell-Thompson, DVM/PhD (University of Florida). (B) Section taken from a pancreas transplant biopsy, from an simultaneous pancreas and kidney (SPK) recipient who had developed recurrence of T1D. Tissues were stained for insulin (red), CD4 T lymphocytes (blue), and CD8 T lymphocytes (teal). Within the insulitic lesions, CTLs represented the dominant T cell found. Figure shows islets with both CD8 than CD4 T cells, but most islets were primarily infiltrated by CD8 T cells. Green/yellow bright stains represent non-specific fluorescence from red blood cells. Image courtesy of Alberto Pugliese, MD, Francesco Vendrame, $\mathrm{MD}$, and George Burke, III, MD, University of Miami.

Biopsy and histological examination of the transplanted pancreas demonstrate the accumulation of high numbers of $\mathrm{CD}^{+} \mathrm{T}$ cells into INS positive islets in patients who are undergoing active islet autoimmunity (Figure 1B).

Regarded as the final executioner in T1D, CTLs mediate direct $\beta$ cell destruction through the recognition of epitopes from proteins that are selectively expressed in $\beta$ cells and are presented by these INS-producing cells the context of MHC-I. Following recognition of cognate antigen, CTLs create a close contact with the target $\beta$ cell by forming an immunological synapse, where several cytotoxic mechanisms are employed to induce death of $\beta$ cells. These include the induction of molecules involved in the granule exocytosis pathway such as perforin, granzyme, or granulysin as well as increased surface expression of death ligands such as Fas Ligand and TNF-related apoptosis inducing ligand (96-98). The presence of CTLs specific for wellknown autoantigens such as IGRP, preproinsulin, and IA-2, have been documented in islets with augmented MHC-I expression $(1,2,88) . \mathrm{CD}^{+} \mathrm{T}$ cells bearing TCR that are specific for $\beta$ cell antigens have been detected in circulation of patients. These TCRs imbue CTL with the ability to destroy human $\beta$ cells in vitro (99-102). In patients undergoing recurrent autoimmunity following islet transplantation, autoreactive $\mathrm{CD}^{+} \mathrm{T}$ cells are associated with $\beta$ cell destruction resulting in graft failure (103). This evidence for an essential role of CTL in T1D in humans is further bolstered by studies in mice. Spontaneous diabetes fails to develop in non-obese diabetic (NOD) mice lacking MHC-I or $\beta 2$ microglobulin $(4,6)$, while diabetes onset can be accelerated by adoptive transfer of diabetogenic CTL $(104,105)$.

Mounting evidence suggests that stimuli from the diabetic islet microenvironment likely contribute to autoreactive CTLmediated $\beta$ cell cytotoxicity. For example, using NOD adoptive transfer systems with IGRP-specific NY8.3 CD8 ${ }^{+} \mathrm{T}$ cells, it has been demonstrated that $\mathrm{CD}^{+} \mathrm{T}$ cells acquire greater cytolytic capacity and an effector-memory phenotype upon migration into the NOD islet (106-108). As T1-IFNs are linked to increased HLA expression in the pancreatic islets of patients with T1D, suggesting that these cytokines contribute to autoimmune surveillance and promote insulitis. While the effect of T1-IFNs on human islets have only recently begun to emerge, evidence suggests that T1-IFNs are involved in the cross talk between the adaptive immune effectors and the microenvironment of the diabetic islet $(16,17,31-36,109,110)$.

\section{TYPE 1 INTERFERONS}

Type 1 interferons belong to a large family of cytokines that were originally described by Alick Issacs and Jean Lindenmann in 1957 as soluble factors responsible for mediating viral interference following a primary virus exposure (111-113). Since then, this large family of cytokines has been further categorized into three distinct classes that play essential roles in cellular-mediated defense against viral and microbial infections as well as in autoimmunity (113-116). Differing in structural homology and signaling receptor complexes, these categories include the T1-IFNs as well as the type 2 interferon [interferon gamma (IFN $\gamma$ )] and the recently identified type III IFNs including IFN $\lambda 1$ (IL-29), IFN $\lambda 2$ (IL-28A), IFN $\lambda 3$ (IL-28B), and IFN $\lambda 4$ (114, 117-121). T1-IFNs signal through the heterodimeric IFNAR1-IFNAR2 receptor [IFNAR] and comprises the largest class of IFN including thirteen IFN $\alpha$ subtypes in addition to IFN $\beta$, IFN $\varepsilon$, IFNא, and IFN $\omega$. Though multiple T1-IFN subtypes may appear redundant, these distinct entities display unique binding affinities to the IFNAR that result in diverse functional outcomes with respect to antiviral, immunomodulatory, and growth inhibitory activity (122-128). While all T1-IFN subtypes contain several conserved "anchoring" residues that are important for receptor binding, the contribution of residues flanking these anchor 
points determine the overall binding of these polypeptides to IFNAR1/2 (126-130). As such, IFN $\beta$ exhibits the strongest interaction with the receptor out of all T1-IFN subtypes (130).

Type 1 interferons represent an early line of defense against viral infection and can be produced by virtually every cell in the body (131-134). Induction of T1-IFNs are initiated by stimulation of pattern recognition receptors (PRRs) that recognize conserved motifs found on viruses, including toll-like receptors (TLR3, TLR4, TLR7, and TLR9), cytosolic RNA helicases (RIG-I and MDA-5), and cytosolic DNA sensors (131, 133, 134). Following activation of these distinct pathways, the adaptor molecules MAVS (cytosolic RNA sensors), STING (cytosolic DNA sensors), TRIF (TLR3/4), and MyD88 (TLR7/8/9) transduce signals that converge on the activation of TBK-1, which phosphorylates IRF-3 leading to transcription of T1-IFN and IRF-7 that engage in a positive feedback loop for amplification of this response (134-136).

Following production, T1-IFNs signal in an autocrine or paracrine fashion through IFNAR. Engagement of the receptor leads to trans-phosphorylation as well as activation of the tyrosine kinases TYK2 and JAK1 that are constitutively associated with the IFNAR subunits, IFNAR1 and IFNAR2, respectively. Signaling downstream of IFNAR can lead to the activation of several pathways that contribute to the widespread range of effects by T1-IFNs depending upon the cell type and the context in which the TI-IFN signal was received (117, 133, 137, 138). Classically, T1-IFN signaling invokes the activation of STAT1-STAT2 heterodimers that rapidly translocate to the nucleus and complex with IRF9 to form the interferonstimulated gene factor 3 (ISGF3) complex. Formation of ISGF3 leads to binding of the interferon response element (consensus sequence: TTTCNNTTTC) for the transcription of interferonstimulated genes (ISGs) that mediate a diverse range of functions $(117,133,139)$. Alternatively, T1-IFNs are capable of activating all seven members of the STAT family that can manifest as homodimers or heterodimers to induce downstream signaling and transcription. For instance, T1-IFN induced STAT1 homodimers are known to bind IFN $\gamma$ activated sequences (GAS; consensus sequence: TTCNNNGAA) to initiate proinflammatory programs similar to IFN $\gamma$, whereas T1-IFN induced STAT3 homodimers have been reported to interact with the corepressor complex SIN3A to indirectly counteract inflammatory responses (133, 140-142). Utilization of these alternative T1-IFN signaling pathways is partially determined by the expression of individual STAT family members (143). This concept is clearly evident in lymphocytes. The balance between STAT1 and STAT4 dictates T cell responses following T1-IFN exposure (144). This is highly dependent upon STAT4 expression within the T cell, which is initially induced through activation of TCR signaling. This induces a switch from the "classical" anti-proliferative and proapoptotic actions of STAT1 signaling to STAT4 that promotes T cell proliferation, differentiation, and survival (143-145).

In addition to JAK-STAT signaling, several other noncanonical pathways are known to be induced by T1-IFNs. For example, activation of JAK1 and TYK2 after T1-IFN engagement has been shown to induce the PI3K-AKT pathway that leads to activation of mTOR, which leads to downstream control of protein translation, regulation of cellular division, and proliferation, in addition to activation of IKK $\beta$ resulting in NF- $\kappa B$ activity $(117,137)$. In lymphocytes, the MAPK pathway mediates crosstalk between T1-IFN signaling and the TCR complex resulting in growth inhibition (117). While studies are still ongoing to unmask the complex signaling networks induced by T1-IFNs, the ability of these cytokines to induce a wide array of signaling pathways explains their pleiotropic and sometimes paradoxical biological activities.

Type 1 interferons signaling culminates in the induction of a robust antiviral program. Several key components required for T1-IFN signaling, including STAT1 and IRF9, are also wellknown ISGs that act to reinforce and amplify the IFN response. T1-IFNs also act to enhance host defense and pathogen detection by increasing the expression of several PRRs involved in viral sensing, expression of 2,5 oligoadenylate synthetase (OAS) that facilitates eradication viral RNA, as well as upregulation of proteins that interfere at various steps of the viral life cycle, including viral entry, replication, and viral egress from infected cells (146).

Type 1 interferons dynamically regulate the actions of innate and adaptive immune cells, including the ability to enhance NK cell cytotoxicity as well as the production of IL-1 $\beta$ and IL-18 by macrophages (147). These cytokines are also well known for directly and indirectly influencing $\mathrm{T}$ cell responses that assist in the eradication of invading pathogens or malignant cells $(132,138,147,148)$. IFN $\alpha / \beta$ promote the differentiation and maturation of DCs by enhancing the expression of MHC-I and II along with costimulatory molecules (CD40, CD80, CD83, CD86, 4-1BBL) required for efficient $\mathrm{CD}^{+}$and $\mathrm{CD}^{+} \mathrm{T}$ cell priming $(138,149-151)$. These cytokines promote trafficking of DCs to lymphoid organs, stimulate expression of adhesion molecules, and induce the secretion of chemoattractant molecules that promote communication between DCs and T lymphocytes $(138,152-154)$. In line with their effects on DCs, T1-IFNs promote the activity of antigen-exposed $\mathrm{CD} 8^{+} \mathrm{T}$ cells, by inciting proliferation, enhancing survival, and increasing effector function. Conversely, in antigen-inexperienced $\mathrm{CD}^{+} \mathrm{T}$ cells the T1-IFNs prevent growth and differentiation in an effort to direct a specific $\mathrm{T}$ cell response toward the inciting pathogen (138). While T1-IFNs act to implement numerous mechanisms aimed at thwarting the spread of infection, aberrant activation of this pathway, as seen in autoimmunity, can lead to overactivation of immune cells and perpetuation of tissue damage.

\section{T1-IFNs AND PATHOGENESIS OF T1D}

\section{Evidence in Humans}

The characterization of insulitis in seminal studies by Gepts and Foulis altered the landscape regarding the pathogenesis of T1D to one of an immune etiology. Soon after, it was reported that there was a striking genetic association between the HLA DR locus and T1D onset (155). These findings, along with the notion that class II antigens could be expressed abnormally in other organ-specific autoimmune diseases prompted investigators to hypothesize that altered antigen presentation by pancreatic $\beta$ cells in T1D might explain activation and infiltration of 
autoimmune $\mathrm{T}$ cells found within insulitic lesions (156-158). In 1985, Bottazzo et al. reported that residual $\beta$ cells found in a 12 -year-old recent onset donor were selectively positive for HLA-DR. In addition to noting enhanced expression of HLA-DR, this was also the first report to note enhanced HLA class I expression in insulitic islets the same donor (20). Since the aberrant expression of MHC-II molecules could be induced by IFN $\gamma$ on thyroid follicular cells in autoimmune thyroiditis, it was postulated that IFN $\gamma$ could be acting in a similar manner to induce this uncharacteristic expression in pancreatic $\beta$ cells. While subsequent studies showed that interferons were incapable of directly inducing ectopic expression of MHC-II on pancreatic $\beta$ cells, they were found to be potent inducers of MHC-I expression (21). Subsequent analyses confirmed that MHC-I expression was a prominent phenotype found in patients undergoing islet autoimmunity, especially in normal appearing or inflamed islets containing residual $\beta$ cells $(1,78,159-162)$. Based on the heterogeneity of insulitis in T1D, it was hypothesized that $\beta$ cells could be actively generating soluble mediators that are capable of acting in a paracrine manner to exert affects within the diabetic microenvironment. IFN $\alpha$ represented a prime candidate, as it was known to induce MHC-I in islet tissue and was known to be produced by a wide range of cells (21). The first report to correlate the presence of IFN $\alpha$ in the islets of patients with recent-onset T1D diabetes was published in 1987. Investigators examined 37 pancreata from cadaveric donors with T1D and found that 34 of 37 samples displayed MHC-I hyperexpression. Further, $97 \%$ of patients displaying this feature concurrently exhibited positivity for IFN $\alpha$ by immunocytochemistry (18). Transcript expression of various cytokines, including IFN $\alpha, \operatorname{IFN} \beta, \operatorname{IFN} \gamma$, IL- $1 \beta, \mathrm{TNF} \alpha$, were compared in diabetic and control pancreata. Among the panel of cytokines tested, only IFN $\alpha$ displayed a clear and consistent pattern of augmented expression in patients (19).

Additional lines of evidence implicate a pathogenic role for T1-IFNs in human autoimmune diabetes. The presence of $\beta$ cell-specific autoantibodies signifies the preclinical phase of T1D and serves as an essential biomarker for identifying at-risk individuals (163). Long-term follow up of at risk children enrolled in the BABYDIET and DIPP longitudinal studies reveal T1-IFN inducible signatures in the peripheral blood, which was positively correlated with episodes of upper respiratory infections. The signature was strongest immediately prior to seroconversion and began to decline after the detection of autoantibodies. This time course suggests that activation and production of T1-IFNs may be involved in the early stages of islet autoimmunity $(16,17)$. In accordance with these findings, IFN $\alpha$ in the plasma of patients with T1D was shown to be elevated when compared to controls ( $10.1 \mathrm{U} / \mathrm{mL} ; 69.6 \%$ positivity vs. $0.4 \mathrm{U} / \mathrm{mL}, 0 \%$ positivity, respectively) and plasmacytoid dendritic cells (pDCs), well known for producing T1-IFNs, were observed in the peripheral blood of new-onset patients during diagnosis $(164,165)$. Furthermore, enterovirus RNA, particularly Coxsackievirus B, was identified in $50 \%$ of patients who displayed positivity for IFN $\alpha$ (165).

The half-life of cytokines within the T1-IFN family is relatively short (IFN $\alpha$ : 4-16 h; IFN $\beta$ 1-2 h) and serum levels of IFN begin to decline very rapidly once secreted $(166,167)$. Due to rapid clearance, detection of IFNs in circulation can prove challenging.
To circumvent this, investigators have attempted to use T1-IFN induction pathways, such as Poly(I:C), or the measurement of ISGs in PBMC as surrogate markers for T1-IFN activation when comparing patients and controls $(168,169)$. For example, patients display a higher basal expression of the ISG OAS, as well as increased sensitivity to IFN $\alpha$ exhibited by maximal induction at lower IFN $\alpha$ concentrations when compared to control subjects (168). T1-IFN production was higher from PBMC isolated from patients with T1D compared to controls, whereas IFN $\gamma$ production by isolated PBMC in response to concanavalin A was not different between control and T1D patient samples (169). With respect to the IFN $\alpha$ response, there was no correlation to blood glucose levels, HbA1c, age of onset, disease duration, or ICA positivity, which may point to the importance of genes associated with T1D that are involved in signaling of this pathway (169).

Initiation of islet autoimmunity has been noted in individuals following T1-IFN therapy for chronic hepatitis, multiple sclerosis, as well as hematologic malignancies $(23,24)$. First reported in 1992, T1-IFN-induced autoimmune diabetes was described in a patient with Hepatitis $\mathrm{C}$, who was seropositive before treatment for autoantibodies against both GAD and INS (30). While this complication occurs in a minor subset of patients, half of all cases reporting T1D following IFN therapy were positive for autoantibodies. This suggests that T1-IFNs may precipitate loss of tolerance and self-reactivity in at-risk patients (170). Studies investigating $\beta$ cell function in these patients suggest that T1-IFNs can reduce INS secretion, impair carbohydrate metabolism during an oral glucose challenge, and induce INS dependency over the course of treatment $(171,172)$. Patients who incur T1-IFN-induced autoimmune diabetes to not exhibit normoglycemia when T1-IFN therapy is arrested suggesting that in these patients $\beta$ cell mass is lost to an extent that metabolic control cannot be reestablished.

\section{Evidence in Animal Models of T1D}

Animal models have been indispensable for ascertaining knowledge regarding the cellular and molecular events involved in T1D pathogenesis. Likewise, these models have also been instrumental in elucidating how T1-IFNs contribute to diabetes pathogenesis. One example includes the diabetes prone biobreeding rat (BB-DP rat). These animals emulate some pathologic features observed in human diabetes including polygenic inheritance [including the $\mathrm{MHC}$ ], peripubescent onset, and $\beta$ cell destruction characterized by mononuclear infiltration $(173,174)$. Initial studies conducted in this model demonstrate a dose dependent stimulation of IFN $\alpha$ production by Poly(I:C) that correlates with accelerated diabetes incidence and severity $(175,176)$. Conversely, elevation of serum IFN $\alpha$ in non-diabetes prone Wistar rats did not instigate diabetes, suggesting that T1-IFNs are not pathogenic without an inherent risk for diabetes $(175,176)$. Additionally, investigation into the natural history of diabetes in BBDP rats revealed spontaneous expression of IFN $\alpha$ in the islets of Langerhans prior to insulitis proposing that induction of T1-IFNs in the islet microenvironment may disrupt self-tolerance in this preclinical model (177).

The NOD mouse model has served as the principal animal model for the investigation of causative mechanisms leading 
to autoimmune diabetes (178). Several lines of evidence in the NOD support an association for T1-IFNs in T1D. One of the most striking is the presence of a T1-IFN signature in NOD islets prior to diabetes onset, reminiscent of the signature observed in humans and BBDP rats (31). In 4- to 6-week-old NOD females, T1-IFNs serve as one of the first distinctive signs of pathology in these animals followed by lymphocytic infiltration and synchronized elevation of activation markers in the islet tissue (31). Elevated levels of IFN $\alpha$ and pDC in the pancreatic draining lymph nodes are also reported in 2- to 3-week-old NOD mice (36). This argues that aberrant activation of $\mathrm{pDCs}$, a DC subset that specializes in T1-IFN production, may contribute to the development of this signature, perhaps through ineffective clearance of islet cell debris $(36,179,180)$. Moreover, innate sensing by TLRs represents an essential pathway for the stimulation of T1-IFNs. Accordingly, ablation of MDA-5 (encoded by Ifih1) in NOD mice results in protection from spontaneous T1D development, while NOD mice carrying a single allele of MDA-5 experience slowed progression and reduced incidence (181). MDA-5 $5^{+/}$animals also displayed protection from Coxsackie B4 virus-induced T1D when compared to MDA- $5^{+/+}$littermates that developed disease despite being able to efficiently clear the virus (181). Further investigations have revealed that CB4 infection of $\mathrm{MDA}-5^{+/-}$mice resulted in a transient increase in IFN $\beta$ that returned to baseline by 7 days postinfection, while IFN $\beta$ levels in $\mathrm{MDA}-5^{+/+}$mice remain consistently elevated after infection (181). These data suggest that protective allotypes of MDA-5 may act in a similar manner to tightly regulate IFN production while keeping antiviral defense mechanisms intact (181). Accordingly, stimulation of TLR7, which recognizes ssRNA to promote T1-IFN production, results in accelerated T1D onset in NOD animals, whereas abrogation of TLR9 signaling, important for the response to unmethylated DNA, retards progressive islet destruction $(182,183)$. Inhibition of T1-IFN signaling through the heterodimeric IFNAR has presented conflicted results. Incidence in NOD and NOD.IFNAR $1^{-1-}$ was indistinguishable, however short-course administration of an IFNAR1 blocking antibody to NOD animals 15-25 postpartum significantly delayed the onset of diabetes $(36,184,185)$. Recently, CRISPRCas9 deletion of the IFNAR1 subunit in LEW.1WR1 rats, a newly described animal model for T1D, caused delayed onset and frequency of Poly(I:C) induced diabetes $(186,187)$. Taken together, these data support the idea that coordinated activation of T1-IFN is an early event in autoimmune diabetes but its role in disease progression is likely heavily influenced by the immune response to environmental cues and inheritance of risk/resistance alleles in genes that impact T1-IFN production or signaling.

Utilization of transgenic model systems during the late 20th century provided strong evidence that T1-IFNs may act to accelerate diabetes pathogenesis. Overexpression of IFN $\alpha$ or IFNא in pancreatic $\beta$ cells of mice not normally prone to T1D leads to onset of diabetes with severe insulitis, hypoinsulinemia, and diabetes $(35,188)$. Transgenic mice expressing of IFN $\beta$ under the control of the rat INS promoter display various phenotypes depending on genetic background. For example, C57BL6/SJL mice with the RIP-IFN $\beta$ transgene do not develop overt diabetes, but display mild hyperglycemia with decreased glucose-stimulated INS secretion and impaired glucose tolerance characteristic of a prediabetic state (34). However, overexpression of IFN $\beta$ in the islets of other mouse strains that are not prone to developing T1D, including the non-obese diabetes resistant, induced spontaneous diabetes development $(34,189)$. Moreover, NOD RIP-IFN $\beta$ mice had accelerated and fulminant onset of T1D (189). Taken together, these data demonstrate that T1-IFNs can act as a spark leading to autoimmunity but only in individuals that possess an inherent risk for development of T1D. Further, these data demonstrate that T1-IFNs in the islet microenvironment result in deleterious effects on $\beta$ cell function and viability by promoting islet inflammation.

\section{T1-IFNs ARE MAJOR PLAYERS IN T1D}

Although T1-IFNs have been associated with the induction of T1D and have been identified as a consistent component of the islet autoinflammatory milieu, the direct impact of these cytokines on the pancreatic $\beta$ cell, cytotoxic T-lymphocytes, and other cellular constituents within the islet that facilitate ongoing islet autoimmunity have only recently been studied using human systems $(18,19,160,190)$. The defining feature observed in T1D is the hyper expression of MHC-I in the islets of patients with $\mathrm{T} 1 \mathrm{D}$, suggesting enhanced $\beta$ cell immunogenicity and increased susceptibility for targeting by CTLs $(1,2,18,19,190)$. T1-IFN represent a likely candidate within the local microenvironment capable of mediating this effect, as IFN $\alpha / \beta$ have been shown to directly induce $\mathrm{MHC}$ expression on primary human islet cells [Figure 2 and $(21,109)$ ]. Recent findings by Marroqui et al. demonstrate that IFN $\alpha$ induced HLA is dependent upon canonical T1-IFN signaling, with TYK2, STAT2, and IRF9 being critically required for induction of HLA class I (109). Another notable finding within the islets of new onset T1D patients is elevated levels of the chemoattractant, CXCL10 (191, 192). Touted as a well-known ISG, CXCL10 is induced by IFN $\alpha$ in primary human islets (109). Our laboratory has corroborated these data, showing that exposure of primary islets to T1-IFN results in significant increases in cell surface Class I HLA by flow cytometry as well as increased mRNA expression of MHC-I and CXCL10 by transcriptome analysis (193). Furthermore, we also find upregulation of transcripts critically required for the MHC-I antigen processing and presentation. Enhanced expression of immunoproteasome subunits PSMB8 and PSMB9 (Figure 2) along with proteasome activator subunits PSME1 and PSME2 by T1-IFN suggests an increased efficiency of peptide generation under conditions of inflammatory stress and ATP depletion (194-196). Analysis of constituents of the peptide loading complex following T1-IFN exposure reveal a significant increase in TAP1, TAP2, TAPBP, chaperones, and the editing enzyme ERAP1 suggesting increased transport, stable processing, and loading of peptides onto MHC-I within the endoplasmic reticulum (ER) [(196) and Figure 2]. Additionally, there is a global augmentation of antigen processing and enhanced surface MHC-I with functional reductions in $\beta$ cell mass, as priming of $\beta$ cells with T1-IFN results in enhanced CTL-induced lysis by chromium release assay [(193) and Figure 2]. 


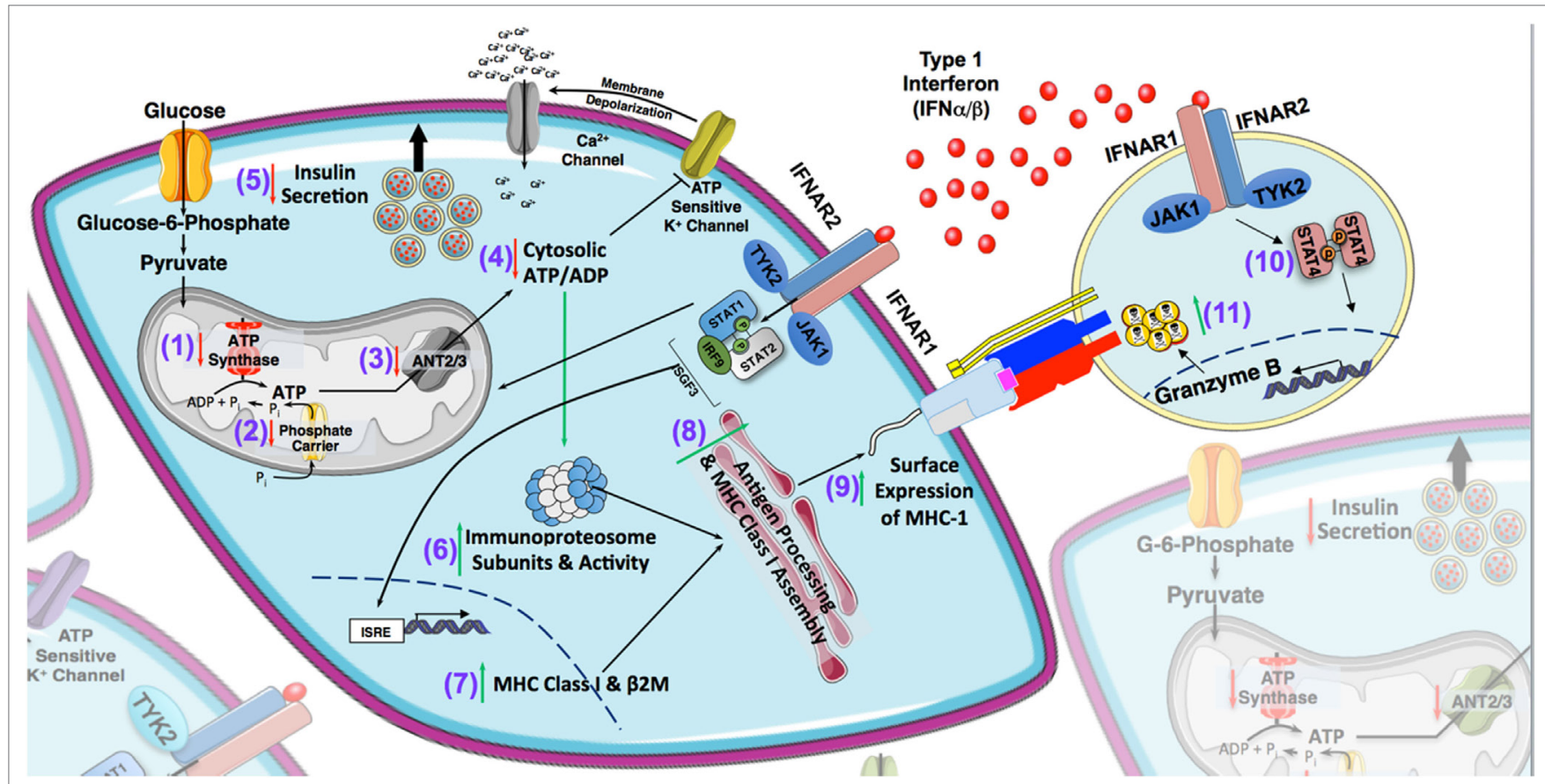

FIGURE 2 | Type 1 interferons (T1-IFNs) are a catastrophic feature of the islet microenvironment in type 1 diabetes (T1D). Based on previous literature and current findings, T1-IFNs are consistently found in the islet autoinflammatory milieu and represent a viable signal that may precipitate diabetogenicity in T1D. With respect to $\beta$ cells, these cytokines can impair insulin secretory function, possibly through the induction of endoplasmic reticulum (ER) stress as well as by impairing mitochondrial bioenergetics. Whole transcriptome analysis reveals decreased expression of genes involved in the regulation of ATP production and transport, including ATP5A (1), SLC25A3 (2), and SLC25A5/6 (3). Reduction in these transcripts likely lead to decreases in the cytosolic ATP/ADP ratio (4) that is required for glucose-stimulated insulin secretion by $\beta$ cells (5). T1-IFNs also enhance the autoimmune surveillance of pancreatic $\beta$ cells through induction of the immunoproteasome (6), de novo synthesis of MHC class I and genes responsible for the peptide loading complex (7 and 8), as well as enhanced surface expression of $\mathrm{MHC}$ class I (9). This increased capacity for antigen presentation results in a functional ability of cytotoxic CD8 ${ }^{+} \mathrm{T}$ lymphocyte (CTL)-mediated $\beta$ cell destruction, which is further augmented by the ability of T1-IFN to amplify infiltrating CTL cytotoxic capacity through STAT4-induced granzyme B production (10 and 11).

Two recent studies have noted the impact of IFN $\alpha$ on $\beta$ cells. Using IFN $\alpha$ both groups determined that this cytokine induced the unfolded protein response (UPR) leading to ER stress. However, neither publication reported negative impacts on $\beta$ cell viability, suggesting that ER stress induced by IFN $\alpha$ did not impact cell death, and there was no reported functional changes $(109,110)$. While these two studies demonstrate increased expression of markers that signal ER stress, the induction of this response differed in timing and severity, which likely points to differences in experimental design and methodology $(109,110)$. Indeed, these reports utilized different culture conditions including different media formulations as well as very different time courses of study. For instance, Marroqui et al. revealed an elevated expression of ATF3 and CHOP in primary human islets following $24 \mathrm{~h}$ of IFN $\alpha(2,000 \mathrm{U} / \mathrm{mL})$ exposure (109). The study conducted by Lombardi and Tomer more widespread induction of the UPR and also assessed INS secretory function in primary human islets and EndoC- $\beta \mathrm{H} 1$ cells after 2 days of exposure to $1,000 \mathrm{U} / \mathrm{mL}$ of IFN $\alpha$. They detected no alterations in glucose stimulated INS secretion, but did correlate the induction of ER stress with reductions in INS content, increased proinsulin to INS ratio, in addition to reduced expression of prohormone convertases, PC1, and PC2 (110). Although ER stress has been a frequently hypothesized explanation for $\beta$ cell dysfunction in T1D, the idea that IFN $\alpha$ elicits expression of genes involved in the UPR presents a conundrum $(197,198)$. Previous reports demonstrate that ER stress actually impairs MHC-I expression. These differences in findings of these two recent publications with the discordance of coexisting ER stress and enhanced ER antigen processing highlight the need for a greater understanding of how the numerous signals provoked by T1-IFN alter the $\beta$ cell in T1D (199-201). Further inspection of metabolic pathways responsible for coordinating INS secretion in $\beta$ cells by transcriptome analysis revealed a decreased expression ATP5A1, a subunit required for ATP production by ATP synthase; decreased expression of adenine nucleotide translocases 2 and 3 (SLC25A5 and SLC25A6), responsible for regulating mitochondrial ATP export, and decreased expression of the mitochondrial phosphate carrier, SLC25A3 [(193) and Figure 2]. A reduction in these genes will likely have major implications on regulation of glucose-stimulated secretion as they directly alter ATP/ADP ratios that are required to trigger islet cell depolarization that leads to release of INS secretory granules.

Another very important component of the islet microenvironment is vascular endothelial cells that facilitate delivery of 
oxygen and enable the rapid exchange of nutrients and hormones between the blood and the endocrine pancreas. These cells also act as a barrier to intricately regulate trafficking and extravasation of autoreactive immune cells into the islet microenvironment. Several studies have shown that endothelial cells in and around the islets display an activated phenotype that likely contributes to increased homing and recruitment of autoreactive T cells (202). Immunohistochemical studies examining endothelium within the pancreata of recent onset patients with T1D reveal elevated expression of ICAM-1 as well as hyperexpression of MHC-I and -II $(83,190,203)$. Expression of these molecules has also been associated with concomitant expression of IFN $\alpha$ (190). In line with these studies, IFN $\alpha$ is known to directly induce MHC-I and expression of ICAM-1 in endothelial cells, suggesting that these cytokines may increase the capacity for antigen presentation required for autoreactive CTLs to gain entry into the islet (204, 205). Additionally, human pancreatic islet endothelial cells are able to be infected by coxsackievirus B resulting in the production of IFN $\alpha$, induction of adhesion molecules, and increased interaction with immune cells (206). Mounting evidence suggest that the crosstalk between $\beta$ cells and the endothelium is important for INS secretory function (207). However, more investigation into the role of T1-IFNs in modulating this interaction is warranted.

It is well known that tissue microenvironments are key determinants in driving local immune responses models of cancer and infectious disease. While armed with the ability to modulate the innate and adaptive arms of the immune system, the impact of T1-IFN within the islet microenvironment has not been fully elucidated. Known to contribute to $\mathrm{T}$ cell priming and activation through their effects on DCs, T1-IFNs have been directly shown to mediate DC maturation and migration even in the absence of PPR engagement $(208,209)$. Specifically, they facilitate the metabolic switch from oxidative phosphorylation to glycolysis through regulation of the transcription factor HIF- $1 \alpha$, inducing the upregulation of MHC-I in these cells as well as costimulatory molecules $(208,209)$. In the case of the autoimmune diabetogenic microenvironment, the presence of T1-IFNs may act to promote DC immunogenicity skewing toward proinflammatory immune activation in addition to augmenting the function of islet infiltrating immune cells, such as $\mathrm{CD}^{+} \mathrm{T}$ cells. Studies completed in our laboratory suggest that T1-IFN drastically augment cytotoxicity elicited by human islet-reactive CTLs. Extensive characterization of T1-IFN signaling mechanisms within these cells show that these cytokines can induce a remarkably rapid acquisition of effector function through induction and direct binding of pSTAT4 to the promoter of Granzyme B (Figure 2). In accordance with studies exhibiting full acquisition of autoreactive CTL effector function within the pancreatic microenvironment, these novel studies implicate T1-IFN as a putative innate signal capable of driving CTL differentiation in the islet (106).

\section{CONCLUSION AND MODEL DETAILING HOW IFN $\alpha$ CAN WREAK HAVOC IN THE DIABETIC MICROENVIRONMENT}

Several determinants predict an individual's susceptibility to T1D. It is well appreciated that the immune system plays a critical role in diminishing $\beta$ cell mass, precipitating the onset of persistent hyperglycemia. Critical to this destruction is the presence of $\mathrm{CD}^{+} \mathrm{T}$ cells within the diabetic microenvironment. These cells enter the pancreas where they directly target and kill $\beta$ cells through interactions of the TCR with elevated MHC-I expression on $\beta$ cells. Soluble factors, such as T1-IFNs, act to promote islet autoimmunity. In addition to being linked to the hallmark HLA class I hyper-expression observed in islets of patients with T1D, T1-IFNs are also well known for their wide-ranging effects including modulation of innate and adaptive immune responses, especially in T lymphocytes. However, until now, few studies to date have focused on elucidating how T1-IFN signaling transforms the islet to an environment that promotes diabetogenicity. The work reviewed here demonstrates that T1-IFNs are stimuli that promote dysfunction and increased visibility of target $\beta$ cells alongside enhanced CTL effector function leading to $\beta$ cell destruction.

Association of T1-IFN with T1D reported in previous studies together with our current findings makes a strong case that these cytokines play some role in the complexity of the diabetes puzzle (summarized in Figure 2). It is likely that a genetic predisposition skewed toward dysfunctional T1-IFN responses create an islet environment permissive to enhanced autoantigen presentation, augmented human $\beta$ cell-specific cytotoxicity by autoreactive CTLs and resulting $\beta$ cell dysfunction. While the pleiotropic actions of T1-IFNs are designed to strengthen the immune response to viral pathogens, this response proves detrimental in the case of autoimmunity where the immune response is misdirected toward self and in this way can promote $\beta$ cell death in T1D.

\section{AUTHOR CONTRIBUTIONS}

This manuscript was conceived by $\mathrm{BN}$ and CM. Interpretation of data/results and discussion were completed by BN and CM. Manuscript was written and revised by BN and CM.

\section{ACKNOWLEDGMENTS}

The authors would like to graciously thank Dr. Martha Campbell-Thompson (University of Florida, Gainesville, FL, USA) and Dr. Alberto Pugliese (University of Miami, Miami, FL, USA) for providing us with the images of the pancreatic sections containing insulitis. In addition, the authors thank nPOD staff members for donor recovery, data collection, and helpful discussions. This work was supported by grants from the National Institutes of Health National Institute of Diabetes, Digestive, and Kidney Diseases (NIH-NIDDK): UC4-DK104194 (CEM), UC4-DK104155 (CEM), and F30-DK105788 (BNN) as well as the NIH National Institute of Allergy and Infectious Diseases (NIH-NIAID): P01-A1042288 (CEM). Human organ donor tissue samples were collected by nPOD according to UF IRB approved protocols following the provision of written informed consent by the donor's family as described at https://www.jdrfnpod.org/for-investigators/ standard-operating-procedures/. 


\section{REFERENCES}

1. Coppieters KT, Dotta F, Amirian N, Campbell PD, Kay TW, Atkinson MA, et al. Demonstration of islet-autoreactive CD8 T cells in insulitic lesions from recent onset and long-term type 1 diabetes patients. J Exp Med (2012) 209:51-60. doi:10.1084/jem.20111187

2. Willcox A, Richardson SJ, Bone AJ, Foulis AK, Morgan NG. Analysis of islet inflammation in human type 1 diabetes. Clin Exp Immunol (2009) 155:173-81. doi:10.1111/j.1365-2249.2008.03860.x

3. Katz J, Benoist C, Mathis D. Major histocompatibility complex class I molecules are required for the development of insulitis in non-obese diabetic mice. Eur J Immunol (1993) 23:3358-60. doi:10.1002/eji.1830231244

4. Serreze DV, Leiter EH, Christianson GJ, Greiner D, Roopenian DC. Major histocompatibility complex class I-deficient NOD-B2mnull mice are diabetes and insulitis resistant. Diabetes (1994) 43:505-9. doi:10.2337/ diabetes.43.3.505

5. Sumida T, Furukawa M, Sakamoto A, Namekawa T, Maeda T, Zijlstra M, et al. Prevention of insulitis and diabetes in beta 2-microglobulin-deficient non-obese diabetic mice. Int Immunol (1994) 6:1445-9. doi:10.1093/ intimm/6.9.1445

6. Wicker LS, Leiter EH, Todd JA, Renjilian RJ, Peterson E, Fischer PA, et al. Beta 2-microglobulin-deficient NOD mice do not develop insulitis or diabetes. Diabetes (1994) 43:500-4. doi:10.2337/diab.43.3.500

7. Dabelea D, Mayer-Davis EJ, Saydah S, Imperatore G, Linder B, Divers J, et al. Prevalence of type 1 and type 2 diabetes among children and adolescents from 2001 to 2009. JAMA (2014) 311:1778-86. doi:10.1001/jama. 2014.3201

8. Patterson CC, Dahlquist GG, Gyurus E, Green A, Soltesz G, EURODIAB Study Group. Incidence trends for childhood type 1 diabetes in Europe during 1989-2003 and predicted new cases 2005-20: a multicentre prospective registration study. Lancet (2009) 373:2027-33. doi:10.1016/S0140-6736 (09)60568-7

9. Patterson CC, Gyurus E, Rosenbauer J, Cinek O, Neu A, Schober E, et al. Trends in childhood type 1 diabetes incidence in Europe during 1989-2008: evidence of non-uniformity over time in rates of increase. Diabetologia (2012) 55:2142-7. doi:10.1007/s00125-012-2571-8

10. Harjutsalo V, Sjoberg L, Tuomilehto J. Time trends in the incidence of type 1 diabetes in Finnish children: a cohort study. Lancet (2008) 371:1777-82. doi:10.1016/S0140-6736(08)60765-5

11. Barrett JC, Clayton DG, Concannon P, Akolkar B, Cooper JD, Erlich HA, et al. Genome-wide association study and meta-analysis find that over 40 loci affect risk of type 1 diabetes. Nat Genet (2009) 41:703-7. doi:10.1038/ ng.381

12. Concannon P, Rich SS, Nepom GT. Genetics of type 1A diabetes. N Engl J Med (2009) 360:1646-54. doi:10.1056/NEJMra0808284

13. Eringsmark Regnéll S, Lernmark A. The environment and the origins of islet autoimmunity and type 1 diabetes. Diabet Med (2013) 30:155-60. doi:10.1111/dme.12099

14. Craig ME, Nair S, Stein H, Rawlinson WD. Viruses and type 1 diabetes: a new look at an old story. Pediatr Diabetes (2013) 14:149-58. doi:10.1111/ pedi. 12033

15. Stene LC, Gale EA. The prenatal environment and type 1 diabetes. Diabetologia (2013) 56:1888-97. doi:10.1007/s00125-013-2929-6

16. Ferreira RC, Guo H, Coulson RM, Smyth DJ, Pekalski ML, Burren OS, et al. A type I interferon transcriptional signature precedes autoimmunity in children genetically at-risk of type 1 diabetes. Diabetes (2014) 63(7):2538-50. doi:10.2337/db13-1777

17. Kallionpaa H, Elo LL, Laajala E, Mykkanen J, Ricano-Ponce I, Vaarma M, et al. Innate immune activity is detected prior to seroconversion in children with HLA-conferred type 1 diabetes susceptibility. Diabetes (2014) 63(7):2402-14. doi: $10.2337 / \mathrm{db} 13-1775$

18. Foulis AK, Farquharson MA, Meager A. Immunoreactive alpha-interferon in insulin-secreting beta cells in type 1 diabetes mellitus. Lancet (1987) 2:1423-7. doi:10.1016/S0140-6736(87)91128-7

19. Huang X, Yuang J, Goddard A, Foulis A, James RF, Lernmark A, et al. Interferon expression in the pancreases of patients with type I diabetes. Diabetes (1995) 44:658-64. doi:10.2337/diabetes.44.6.658

20. Bottazzo GF, Dean BM, McNally JM, MacKay EH, Swift PG, Gamble DR. In situ characterization of autoimmune phenomena and expression of
HLA molecules in the pancreas in diabetic insulitis. N Engl J Med (1985) 313:353-60. doi:10.1056/NEJM198508083130604

21. Pujol-Borrell R, Todd I, Doshi M, Gray D, Feldmann M, Bottazzo GF. Differential expression and regulation of $\mathrm{MHC}$ products in the endocrine and exocrine cells of the human pancreas. Clin Exp Immunol (1986) 65:128-39.

22. Todd JA. Etiology of type 1 diabetes. Immunity (2010) 32:457-67. doi:10.1016/j.immuni.2010.04.001

23. Uonaga T, Yoshida K, Harada T, Shimodahira M, Nakamura Y. Case of type 1 diabetes mellitus following interferon beta-1a treatment for multiple sclerosis. Intern Med (2012) 51:1875-7. doi:10.2169/internalmedicine. 51.7609

24. Nakamura K, Kawasaki E, Imagawa A, Awata T, Ikegami H, Uchigata Y, et al. Type 1 diabetes and interferon therapy: a nationwide survey in Japan. Diabetes Care (2011) 34:2084-9. doi:10.2337/dc10-2274

25. Oka R, Hiroi N, Shigemitsu R, Sue M, Oshima Y, Yoshida-Hiroi M. Type 1 diabetes mellitus associated with pegylated interferon-alpha plus Ribavirin treatment for chronic hepatitis C: case report and literature review. Clin Med Insights Endocrinol Diabetes (2011) 4:39-45. doi:10.4137/CMED.S7815

26. Kado S, Miyamoto J, Komatsu N, Iwaki Y, Ozaki H, Taguchi H, et al. Type 1 diabetes mellitus caused by treatment with interferon-beta. Intern Med (2000) 39:146-9. doi:10.2169/internalmedicine.39.146

27. Fabris P, Betterle C, Greggio NA, Zanchetta R, Bosi E, Biasin MR, et al. Insulindependent diabetes mellitus during alpha-interferon therapy for chronic viral hepatitis. J Hepatol (1998) 28:514-7. doi:10.1016/S0168-8278(98) 80328-0

28. Shiba T, Morino Y, Tagawa K, Fujino H, Unuma T. Onset of diabetes with high titer anti-GAD antibody after IFN therapy for chronic hepatitis. Diabetes Res Clin Pract (1995) 30:237-41. doi:10.1016/0168-8227(95)01188-9

29. Guerci AP, Guerci B, Levy-Marchal C, Ongagna J, Ziegler O,Candiloros H, et al. Onset of insulin-dependent diabetes mellitus after interferon-alfa therapy for hairy cell leukaemia. Lancet (1994) 343:1167-8. doi:10.1016/S0140 6736(94)90276-3

30. Fabris P, Betterle C, Floreani A, Greggio NA, de Lazzari F, Naccarato R, et al. Development of type 1 diabetes mellitus during interferon alfa therapy for chronic HCV hepatitis. Lancet (1992) 340:548. doi:10.1016/0140-6736 (92)91744-S

31. Carrero JA, Calderon B, Towfic F, Artyomov MN, Unanue ER. Defining the transcriptional and cellular landscape of type 1 diabetes in the NOD mouse. PLoS One (2013) 8:e59701. doi:10.1371/journal.pone.0059701

32. Santin I, Moore F, Grieco FA, Marchetti P, Brancolini C, Eizirik DL. USP18 is a key regulator of the interferon-driven gene network modulating pancreatic beta cell inflammation and apoptosis. Cell Death Dis (2012) 3:e419. doi:10.1038/cddis. 2012.158

33. Nakanishi K, Saitoh S. Clinical and genetic characteristics of patients with type 1 diabetes associated with interferon therapy. Diabetes Care (2011) 34:471-3. doi:10.2337/dc10-1237

34. Pelegrin M, Devedjian JC, Costa C, Visa J, Solanes G, Pujol A, et al. Evidence from transgenic mice that interferon-beta may be involved in the onset of diabetes mellitus. J Biol Chem (1998) 273:12332-40. doi:10.1074/ jbc.273.20.12332

35. Stewart TA, Hultgren B, Huang X, Pitts-Meek S, Hully J, MacLachlan NJ. Induction of type I diabetes by interferon-alpha in transgenic mice. Science (1993) 260:1942-6. doi:10.1126/science.8100367

36. Li Q, Xu B, Michie SA, Rubins KH, Schreriber RD, McDevitt HO. Interferon-alpha initiates type 1 diabetes in nonobese diabetic mice. Proc Natl Acad Sci U S A (2008) 105:12439-44. doi:10.1073/pnas.0806439105

37. Bradfield JP, Qu HQ, Wang K, Zhang H, Sleiman PM, Kim CE, et al. A genome-wide meta-analysis of six type 1 diabetes cohorts identifies multiple associated loci. PLoS Genet (2011) 7:e1002293. doi:10.1371/journal pgen.1002293

38. Pociot F. Lernmark Å: genetic risk factors for type 1 diabetes. Lancet (2016) 387:2331-9. doi:10.1016/S0140-6736(16)30582-7

39. Clayton DG. Prediction and interaction in complex disease genetics: experience in type 1 diabetes. PLoS Genet (2009) 5:e1000540. doi:10.1371/journal. pgen. 1000540

40. Erlich H, Valdes AM, Noble J, Carlson JA, Varney M, Concannon P, et al. HLA DR-DQ haplotypes and genotypes and type 1 diabetes risk: analysis of the type 1 diabetes genetics consortium families. Diabetes (2008) 57:1084-92. doi: $10.2337 / \mathrm{db} 07-1331$ 
41. Sheehy MJ, Scharf SJ, Rowe JR, Neme de Gimenez MH, Meske LM, Erlich HA, et al. A diabetes-susceptible HLA haplotype is best defined by a combination of HLA-DR and -DQ alleles. JClin Invest (1989) 83:830-5. doi:10.1172/ JCI113965

42. Ettinger RA, Kwok WW. A peptide binding motif for HLA-DQA ${ }^{*} 0102 /$ $\mathrm{DQB} 1^{*} 0602$, the class II MHC molecule associated with dominant protection in insulin-dependent diabetes mellitus. J Immunol (1998) 160:2365-73.

43. Ettinger RA, Papadopoulos GK, Moustakas AK, Nepom GT, Kwok WW. Allelic variation in key peptide-binding pockets discriminates between closely related diabetes-protective and diabetes-susceptible HLA-DQB1 ${ }^{*} 06$ alleles. J Immunol (2006) 176:1988-98. doi:10.4049/jimmunol.176.3.1988

44. Todd JA, Bell JI, McDevitt HO. HLA-DQ beta gene contributes to susceptibility and resistance to insulin-dependent diabetes mellitus. Nature (1987) 329:599-604. doi:10.1038/329599a0

45. Horn GT, Bugawan TL, Long CM, Erlich HA. Allelic sequence variation of the HLA-DQ loci: relationship to serology and to insulin-dependent diabetes susceptibility. Proc Natl Acad Sci U S A (1988) 85:6012-6. doi:10.1073/ pnas.85.16.6012

46. Corper AL, Stratmann T, Apostolopoulos V, Scott CA, Garcia KC, Kang AS, et al. A structural framework for deciphering the link between I-Ag7 and autoimmune diabetes. Science (2000) 288:505-11. doi:10.1126/ science.288.5465.505

47. Noble JA, Johnson J, Lane JA, Valdes AM. HLA class II genotyping of African American type 1 diabetic patients reveals associations unique to African haplotypes. Diabetes (2013) 62:3292-9. doi:10.2337/db13-0094

48. Noble JA, Valdes AM, Bugawan TL, Apple RJ, Thomson G, Erlich HA. The HLA class I A locus affects susceptibility to type 1 diabetes. Hum Immunol (2002) 63:657-64. doi:10.1016/S0198-8859(02)00421-4

49. Nakanishi K, Kobayashi T, Murase T, Nakatsuji T, Inoko H, Tsuji K, et al. Association of HLA-A24 with complete beta-cell destruction in IDDM. Diabetes (1993) 42:1086-93. doi:10.2337/diab.42.7.1086

50. Valdes AM, Erlich HA, Noble JA. Human leukocyte antigen class I B and C loci contribute to type 1 diabetes (T1D) susceptibility and age at T1D onset. Hum Immunol (2005) 66:301-13. doi:10.1016/j.humimm.2004.12.001

51. Concannon P, Chen WM, Julier C, Morahan G, Akolkar B, Erlich HA, et al. Genome-wide scan for linkage to type 1 diabetes in 2,496 multiplex families from the type 1 diabetes genetics consortium. Diabetes (2009) 58:1018-22. doi:10.2337/db08-1551

52. Bell GI, Horita S, Karam JH. A polymorphic locus near the human insulin gene is associated with insulin-dependent diabetes mellitus. Diabetes (1984) 33:176-83. doi:10.2337/diabetes.33.2.176

53. Bennett ST, Lucassen AM, Gough SC, Powell EE, Undlien DE, Pritchard LE, et al. Susceptibility to human type 1 diabetes at IDDM2 is determined by tandem repeat variation at the insulin gene minisatellite locus. Nat Genet (1995) 9:284-92. doi:10.1038/ng0395-284

54. Kennedy GC, German MS, Rutter WJ. The minisatellite in the diabetes susceptibility locus IDDM2 regulates insulin transcription. Nat Genet (1995) 9:293-8. doi:10.1038/ng0395-293

55. Pugliese A, Zeller M, Fernandez A, Zalcberg LJ, Bartlett RJ, Ricordi C, et al. The insulin gene is transcribed in the human thymus and transcription levels correlated with allelic variation at the INS VNTR-IDDM2 susceptibility locus for type 1 diabetes. Nat Genet (1997) 15:293-7. doi:10.1038/ ng0397-293

56. Cai CQ, Zhang T, Breslin MB, Giraud M, Lan MS. Both polymorphic variable number of tandem repeats and autoimmune regulator modulate differential expression of insulin in human thymic epithelial cells. Diabetes (2011) 60:336-44. doi:10.2337/db10-0255

57. Bottini N, Musumeci L, Alonso A, Rahmouni S, Nika K, Rostamkhani M, et al. A functional variant of lymphoid tyrosine phosphatase is associated with type I diabetes. Nat Genet (2004) 36:337-8. doi:10.1038/ng1323

58. Vang T, Congia M, Macis MD, Musumeci L, Orrú V, Zavattari P, et al. Autoimmune-associated lymphoid tyrosine phosphatase is a gain-offunction variant. Nat Genet (2005) 37:1317-9. doi:10.1038/ng1673

59. Zhang J, Zahir N, Jiang Q, Miliotis H, Heyraud S, Meng X, et al. The autoimmune disease-associated PTPN22 variant promotes calpain-mediated Lyp/ Pep degradation associated with lymphocyte and dendritic cell hyperresponsiveness. Nat Genet (2011) 43:902-7. doi:10.1038/ng.904

60. Wang Y, Shaked I, Stanford SM, Zhou W, Curtsinger JM, Mikulski Z, et al. The autoimmunity-associated gene PTPN22 potentiates toll-like receptor-driven, type 1 interferon-dependent immunity. Immunity (2013) 39:111-22. doi:10.1016/j.immuni.2013.06.013

61. Bottini N, Peterson EJ. Tyrosine phosphatase PTPN22: multifunctional regulator of immune signaling, development, and disease. Annu Rev Immunol (2014) 32:83-119. doi:10.1146/annurev-immunol-032713-120249

62. Smyth DJ, Cooper JD, Bailey R, Field S, Burren O, Smink LJ, et al. A genomewide association study of nonsynonymous SNPs identifies a type 1 diabetes locus in the interferon-induced helicase (IFIH1) region. Nat Genet (2006) 38:617-9. doi:10.1038/ng1800

63. Wallace C, Smyth DJ, Maisuria-Armer M, Walker NM, Todd JA,Clayton DG. The imprinted DLK1-MEG3 gene region on chromosome 14q32.2 alters susceptibility to type 1 diabetes. Nat Genet (2010) 42:68-71. doi:10.1038/ ng.493

64. Martínez A, Varadé J, Márquez A, Cénit MC, Espino L, Perdigones N, et al. Association of the STAT4 gene with increased susceptibility for some immune-mediated diseases. Arthritis Rheum (2008) 58:2598-602. doi:10.1002/art.23792

65. Richter MF, Duménil G, Uzé G, Fellous M, Pellegrini S. Specific contribution of Tyk2 JH regions to the binding and the expression of the interferon alpha/beta receptor component IFNAR1. J Biol Chem (1998) 273:24723-9. doi:10.1074/jbc.273.38.24723

66. Ragimbeau J, Dondi E, Alcover A, Eid P, Uzé G, Pellegrini S. The tyrosine kinase Tyk2 controls IFNAR1 cell surface expression. EMBO J (2003) 22:537-47. doi:10.1093/emboj/cdg038

67. Marroqui L, Dos Santos RS, Fløyel T, Grieco FA, Santin I, Op de Beeck A, et al. TYK2, a candidate gene for type 1 diabetes, modulates apoptosis and the innate immune response in human pancreatic $\beta$-cells. Diabetes (2015) 64:3808-17. doi:10.2337/db15-0362

68. Holz A, Bot A, Coon B, Wolfe T, Grusby MJ, von Herrath MG. Disruption of the STAT4 signaling pathway protects from autoimmune diabetes while retaining antiviral immune competence. J Immunol (1999) 163:5374-82.

69. Yang Z, Chen M, Ellett JD, Fialkow LB, Carter JD, McDuffie M, et al. Autoimmune diabetes is blocked in Stat4-deficient mice. J Autoimmun (2004) 22:191-200. doi:10.1016/j.jaut.2003.08.006

70. Kariuki SN, Kirou KA, MacDermott EJ, Barillas-Arias L, Crow MK, Niewold TB. Cutting edge: autoimmune disease risk variant of STAT4 confers increased sensitivity to IFN-alpha in lupus patients in vivo. J Immunol (2009) 182:34-8. doi:10.4049/jimmunol.182.1.34

71. Funabiki M, Kato H, Miyachi Y, Toki H, Motegi H, Inoue M, et al. Autoimmune disorders associated with gain of function of the intracellular sensor MDA5. Immunity (2014) 40:199-212. doi:10.1016/j.immuni.2013.12.014

72. Looney BM, Xia CQ, Concannon P, Ostrov DA, Clare-Salzler MJ. Effects of type 1 diabetes-associated IFIH1 polymorphisms on MDA5 function and expression. Curr Diab Rep (2015) 15:96. doi:10.1007/s11892-015-0656-8

73. Domsgen E, Lind K, Kong L, Hühn MH, Rasool O, van Kuppeveld F, et al. Flodström-Tullberg M: An IFIH1 gene polymorphism associated with risk for autoimmunity regulates canonical antiviral defence pathways in Coxsackievirus infected human pancreatic islets. Sci Rep (2016) 6:39378. doi: $10.1038 /$ srep39378

74. Nicholls DG. The pancreatic $\beta$-cell: a bioenergetic perspective. Physiol Rev (2016) 96:1385-447. doi:10.1152/physrev.00009.2016

75. Sosenko JM, Palmer JP, Greenbaum CJ, Mahon J, Cowie C, Krischer JP, et al. Increasing the accuracy of oral glucose tolerance testing and extending its application to individuals with normal glucose tolerance for the prediction of type 1 diabetes: the diabetes prevention trial-type 1. Diabetes Care (2007) 30:38-42. doi:10.2337/dc06-1615

76. Sosenko JM, Palmer JP, Rafkin-Mervis L, Krischer JP, Cuthbertson D, Matheson D, et al. Glucose and C-peptide changes in the perionset period of type 1 diabetes in the diabetes prevention trial-type 1. Diabetes Care (2008) 31:2188-92. doi: 10.2337/dc08-0935

77. Xu P, Wu Y, Zhu Y, Dagne G, Johnson G, Cuthbertson D, et al. Prognostic performance of metabolic indexes in predicting onset of type 1 diabetes. Diabetes Care (2010) 33:2508-13. doi:10.2337/dc10-0802

78. Richardson SJ, Rodriguez-Calvo T, Gerling IC, Mathews CE, Kaddis JS, Russell MA, et al. Islet cell hyperexpression of HLA class I antigens: a defining feature in type 1 diabetes. Diabetologia (2016) 59:2448-58. doi:10.1007/ s00125-016-4067-4

79. Eizirik DL, Sammeth M, Bouckenooghe T, Bottu G, Sisino G, IgoilloEsteve $\mathrm{M}$, et al. The human pancreatic islet transcriptome: expression of 
candidate genes for type 1 diabetes and the impact of pro-inflammatory cytokines. PLoS Genet (2012) 8:e1002552. doi:10.1371/journal.pgen.1002552

80. Eisenbarth G. Autoimmune beta cell insufficiency: diabetes mellitus type 1. Triangle (1984) 23:111-23.

81. Eisenbarth GS. Type I diabetes mellitus. A chronic autoimmune disease. N Engl J Med (1986) 314:1360-8. doi:10.1056/NEJM198605223142106

82. Gepts W. Pathologic anatomy of the pancreas in juvenile diabetes mellitus. Diabetes (1965) 14:619-33. doi:10.2337/diab.14.10.619

83. Hänninen A, Jalkanen S, Salmi M, Toikkanen S, Nikolakaros G, Simell O. Macrophages, T cell receptor usage, and endothelial cell activation in the pancreas at the onset of insulin-dependent diabetes mellitus. J Clin Invest (1992) 90:1901-10. doi:10.1172/JCI116067

84. In't Veld P. Insulitis in human type 1 diabetes: the quest for an elusive lesion. Islets (2011) 3:131-8. doi:10.4161/isl.3.4.15728

85. Gale EA. The discovery of type 1 diabetes. Diabetes (2001) 50:217-26. doi:10.2337/diabetes.50.2.217

86. Gepts W, De Mey J. Islet cell survival determined by morphology. An immunocytochemical study of the islets of Langerhans in juvenile diabetes mellitus. Diabetes (1978) 27(Suppl 1):251-61. doi:10.2337/diab.27.1.S251

87. Foulis AK, Liddle CN, Farquharson MA, Richmond JA, Weir RS. The histopathology of the pancreas in type 1 (insulin-dependent) diabetes mellitus: a 25-year review of deaths in patients under 20 years of age in the United Kingdom. Diabetologia (1986) 29:267-74. doi:10.1007/BF00452061

88. Campbell-Thompson M, Fu A, Kaddis JS, Wasserfall C, Schatz DA, Pugliese A, et al. Insulitis and $\beta$-cell mass in the natural history of type 1 diabetes. Diabetes (2016) 65:719-31. doi:10.2337/db15-0779

89. Campbell-Thompson M. Organ donor specimens: what can they tell us about type 1 diabetes? Pediatr Diabetes (2015) 16:320-30. doi:10.1111/pedi.12286

90. Campbell-Thompson M, Wasserfall C, Kaddis J, Albanese-O'Neill A, Staeva T, Nierras C, et al. Network for Pancreatic Organ Donors with Diabetes (nPOD): developing a tissue biobank for type 1 diabetes. Diabetes Metab Res $\operatorname{Rev}(2012)$ 28:608-17. doi:10.1002/dmrr.2316

91. Pugliese A, Yang M, Kusmarteva I, Heiple T, Vendrame F, Wasserfall C, et al. The juvenile diabetes research foundation Network for Pancreatic Organ Donors with Diabetes (nPOD) program: goals, operational model and emerging findings. Pediatr Diabetes (2014) 15:1-9. doi:10.1111/pedi.12097

92. Kaddis JS, Pugliese A, Atkinson MA. A run on the biobank: what have we learned about type 1 diabetes from the nPOD tissue repository? Curr Opin Endocrinol Diabetes Obes (2015) 22:290-5. doi:10.1097/ MED.0000000000000171

93. Campbell-Thompson ML, Atkinson MA, Butler AE, Chapman NM, Frisk G, Gianani R, et al. The diagnosis of insulitis in human type 1 diabetes. Diabetologia (2013) 56:2541-3. doi:10.1007/s00125-013-3043-5

94. In't Veld P, Lievens D, De Grijse J, Ling Z, Van der Auwera B, PipeleersMarichal M, et al. Screening for insulitis in adult autoantibody-positive organ donors. Diabetes (2007) 56:2400-4. doi:10.2337/db07-0416

95. Zheng S, Mathews CE. Metabolic abnormalities in the pathogenesis of type 1 diabetes. Curr Diab Rep (2014) 14:519. doi:10.1007/s11892-014-0519-8

96. Graham KL, Sutherland RM, Mannering SI, Zhao Y, Chee J, Krishnamurthy B, et al. Pathogenic mechanisms in type 1 diabetes: the islet is both target and driver of disease. Rev Diabet Stud (2012) 9:148-68. doi:10.1900/RDS.2012.9.148

97. Barry M, Bleackley RC. Cytotoxic T lymphocytes: all roads lead to death. Nat Rev Immunol (2002) 2:401-9. doi:10.1038/nri819

98. Fooksman DR, Vardhana S, Vasiliver-Shamis G, Liese J, Blair DA, Waite J, et al. Functional anatomy of T cell activation and synapse formation. Annu Rev Immunol (2010) 28:79-105. doi:10.1146/annurev-immunol-030409-101308

99. Campbell PD, Estella E, Dudek NL, Jhala G, Thomas HE, Kay TW, et al. Cytotoxic T-lymphocyte-mediated killing of human pancreatic islet cells in vitro. Hum Immunol (2008) 69:543-51.doi:10.1016/j.humimm.2008.06.008

100. Schloot NC, Willemen S, Duinkerken G, de Vries RR, Roep BO. Cloned $\mathrm{T}$ cells from a recent onset IDDM patient reactive with insulin B-chain. J Autoimmun (1998) 11:169-75. doi:10.1006/jaut.1997.0183

101. Abreu JR, Martina S, Verrijn Stuart AA, Fillié YE, Franken KL, Drijfhout JW, et al. CD8 T cell autoreactivity to preproinsulin epitopes with very low human leucocyte antigen class I binding affinity. Clin Exp Immunol (2012) 170:57-65. doi:10.1111/j.1365-2249.2012.04635.x

102. Unger WW, Velthuis J, Abreu JR, Laban S, Quinten E, Kester MG, et al. Discovery of low-affinity preproinsulin epitopes and detection of autoreactive CD8 T-cells using combinatorial MHC multimers. J Autoimmun (2011) 37:151-9. doi:10.1016/j.jaut.2011.05.012

103. Pinkse GG, Tysma OH, Bergen CA, Kester MG, Ossendorp F, van Veelen PA, et al. Autoreactive CD8 T cells associated with beta cell destruction in type 1 diabetes. Proc Natl Acad Sci U S A (2005) 102:18425-30. doi:10.1073/pnas.0508621102

104. Wong FS, Visintin I, Wen L, Flavell RA, Janeway CA. CD8 T cell clones from young nonobese diabetic (NOD) islets can transfer rapid onset of diabetes in NOD mice in the absence of CD4 cells. J Exp Med (1996) 183:67-76. doi:10.1084/jem.183.1.67

105. DiLorenzo TP, Graser RT, Ono T, Christianson GJ, Chapman HD, Roopenian DC, et al. Major histocompatibility complex class I-restricted $\mathrm{T}$ cells are required for all but the end stages of diabetes development in nonobese diabetic mice and use a prevalent $\mathrm{T}$ cell receptor alpha chain gene rearrangement. Proc Natl Acad Sci U S A (1998) 95:12538-43. doi:10.1073/ pnas. 95.21 .12538

106. Graham KL, Krishnamurthy B, Fynch S, Mollah ZU, Slattery R, Santamaria $\mathrm{P}$, et al. Autoreactive cytotoxic T lymphocytes acquire higher expression of cytotoxic effector markers in the islets of NOD mice after priming in pancreatic lymph nodes. Am J Pathol (2011) 178:2716-25. doi:10.1016/j.ajpath.2011.02.015

107. Chee J, Ko HJ, Skowera A, Jhala G, Catterall T, Graham KL, et al. Effectormemory $\mathrm{T}$ cells develop in islets and report islet pathology in type 1 diabetes. J Immunol (2014) 192:572-80. doi:10.4049/jimmunol.1302100

108. Graham KL, Krishnamurthy B, Fynch S, Ayala-Perez R, Slattery RM, Santamaria $\mathrm{P}$, et al. Intra-islet proliferation of cytotoxic $\mathrm{T}$ lymphocytes contributes to insulitis progression. Eur J Immunol (2012) 42:1717-22. doi:10.1002/eji.201242435

109. Marroqui L, Dos Santos RS, Op de Beeck A, Coomans de Brachène A, Marselli L, Marchetti P, et al. Interferon- $\alpha$ mediates human beta cell HLA class I overexpression, endoplasmic reticulum stress and apoptosis, three hallmarks of early human type 1 diabetes. Diabetologia (2017) 60:656-67. doi:10.1007/s00125-016-4201-3

110. Lombardi A, Tomer Y. Interferon alpha impairs insulin production in human beta cells via endoplasmic reticulum stress. J Autoimmun (2017) 80:48-55. doi:10.1016/j.jaut.2017.02.002

111. Isaacs A, Lindenmann J. Pillars article: virus interference. I. The interferon. Proc R Soc Lond B Biol Sci. 1957. 147: 258-267. J Immunol (2015) 195:1911-20.

112. Isaacs A, Lindenmann J, Valentine RC. Pillars article: virus interference. II. Some properties of interferon. Proc R Soc Lond B Biol Sci. 1957. 147: 268-273. J Immunol (2015) 195:1921-6.

113. Pestka $S$. The interferons: 50 years after their discovery, there is much more to learn. J Biol Chem (2007) 282:20047-51. doi:10.1074/jbc.R700004200

114. Pestka S, Krause CD, Walter MR. Interferons, interferon-like cytokines, and their receptors. Immunol Rev (2004) 202:8-32. doi:10.1111/j. 0105-2896.2004.00204.x

115. Di Domizio J, Cao W. Fueling autoimmunity: type I interferon in autoimmune diseases. Expert Rev Clin Immunol (2013) 9:201-10. doi:10.1586/eci.12.106

116. Niewold TB. Type I interferon in human autoimmunity. Front Immunol (2014) 5:306. doi:10.3389/fimmu.2014.00306

117. Platanias LC. Mechanisms of type-I- and type-II-interferon-mediated signalling. Nat Rev Immunol (2005) 5:375-86. doi:10.1038/nri1604

118. Kotenko SV, Gallagher G, Baurin VV, Lewis-Antes A, Shen M, Shah NK, et al. IFN-lambdas mediate antiviral protection through a distinct class II cytokine receptor complex. Nat Immunol (2003) 4:69-77. doi:10.1038/ni875

119. Sheppard P, Kindsvogel W, Xu W, Henderson K, Schlutsmeyer S, Whitmore TE, et al. IL-28, IL-29 and their class II cytokine receptor IL-28R. Nat Immunol (2003) 4:63-8. doi:10.1038/ni873

120. Egli A, Santer DM, O'Shea D, Tyrrell DL, Houghton M. The impact of the interferon-lambda family on the innate and adaptive immune response to viral infections. Emerg Microbes Infect (2014) 3:e51. doi:10.1038/emi.2014.51

121. O'Brien TR, Prokunina-Olsson L, Donnelly RP. IFN- $\lambda 4$ : the paradoxical new member of the interferon lambda family. J Interferon Cytokine Res (2014) 34:829-38. doi:10.1089/jir.2013.0136

122. Jaitin DA, Roisman LC, Jaks E, Gavutis M, Piehler J, Van der Heyden J, et al. Inquiring into the differential action of interferons (IFNs): an IFN-alpha2 mutant with enhanced affinity to IFNAR1 is functionally similar to IFN-beta. Mol Cell Biol (2006) 26:1888-97. doi:10.1128/MCB.26.5.1888-1897.2006 
123. Kalie E, Jaitin DA, Podoplelova Y, Piehler J, Schreiber G. The stability of the ternary interferon-receptor complex rather than the affinity to the individual subunits dictates differential biological activities. J Biol Chem (2008) 283:32925-36. doi:10.1074/jbc.M806019200

124. Moraga I, Harari D, Schreiber G, Uzé G, Pellegrini S. Receptor density is key to the alpha2/beta interferon differential activities. Mol Cell Biol (2009) 29:4778-87. doi:10.1128/MCB.01808-08

125. Thomas C, Moraga I, Levin D, Krutzik PO, Podoplelova Y, Trejo A, et al. Structural linkage between ligand discrimination and receptor activation by type I interferons. Cell (2011) 146:621-32. doi:10.1016/j.cell. 2011.06.048

126. de Weerd NA, Samarajiwa SA, Hertzog PJ. Type I interferon receptors: biochemistry and biological functions. J Biol Chem (2007) 282:20053-7. doi:10.1074/jbc.R700006200

127. de Weerd NA, Nguyen T. The interferons and their receptors - distribution and regulation. Immunol Cell Biol (2012) 90:483-91. doi:10.1038/ icb. 2012.9

128. de Weerd NA, Vivian JP, Nguyen TK, Mangan NE, Gould JA, Braniff SJ, et al. Structural basis of a unique interferon-beta signaling axis mediated via the receptor IFNAR1. Nat Immunol (2013) 14:901-7. doi:10.1038/ni.2667

129. Piehler J, Thomas C, Garcia KC, Schreiber G. Structural and dynamic determinants of type I interferon receptor assembly and their functional interpretation. Immunol Rev (2012) 250:317-34. doi:10.1111/imr.12001

130. Ng CT, Mendoza JL, Garcia KC, Oldstone MB. Alpha and beta type 1 interferon signaling: passage for diverse biologic outcomes. Cell (2016) 164:349-52. doi:10.1016/j.cell.2015.12.027

131. Gonzalez-Navajas JM, Lee J, David M, Raz E. Immunomodulatory functions of type I interferons. Nat Rev Immunol (2012) 12:125-35. doi:10.1038/ nri3133

132. Welsh RM, Bahl K, Marshall HD, Urban SL. Type 1 interferons and antiviral CD8 T-cell responses. PLoS Pathog (2012) 8:e1002352. doi:10.1371/journal. ppat. 1002352

133. Ivashkiv LB, Donlin LT. Regulation of type I interferon responses. Nat Rev Immunol (2014) 14:36-49. doi:10.1038/nri3581

134. McNab F, Mayer-Barber K, Sher A, Wack A, O'Garra A. Type I interferons in infectious disease. Nat Rev Immunol (2015) 15:87-103. doi:10.1038/nri3787

135. Honda K, Taniguchi T. IRFs: master regulators of signalling by toll-like receptors and cytosolic pattern-recognition receptors. Nat Rev Immunol (2006) 6:644-58. doi:10.1038/nri1900

136. Tamura T, Yanai H, Savitsky D, Taniguchi T. The IRF family transcription factors in immunity and oncogenesis. Annu Rev Immunol (2008) 26:535-84. doi:10.1146/annurev.immunol.26.021607.090400

137. Theofilopoulos AN, Baccala R, Beutler B, Kono DH. Type I interferons (alpha/beta) in immunity and autoimmunity. Annu Rev Immunol (2005) 23:307-36. doi:10.1146/annurev.immunol.23.021704.115843

138. Crouse J, Kalinke U, Oxenius A. Regulation of antiviral T cell responses by type I interferons. Nat Rev Immunol (2015) 15:231-42. doi:10.1038/ nri3806

139. Stark GR, Darnell JE. The JAK-STAT pathway at twenty. Immunity (2012) 36:503-14. doi:10.1016/j.immuni.2012.03.013

140. Wang WB, Levy DE, Lee CK. STAT3 negatively regulates type I IFNmediated antiviral response. J Immunol (2011) 187:2578-85. doi:10.4049/ jimmunol.1004128

141. Murray PJ. The JAK-STAT signaling pathway: input and output integration. J Immunol (2007) 178:2623-9. doi:10.4049/jimmunol.178.5.2623

142. Ho HH, Ivashkiv LB. Role of STAT3 in type I interferon responses. Negative regulation of STAT1-dependent inflammatory gene activation. J Biol Chem (2006) 281:14111-8. doi:10.1074/jbc.M511797200

143. Kallal LE, Biron CA. Changing partners at the dance: variations in STAT concentrations for shaping cytokine function and immune responses to viral infections. JAKSTAT (2013) 2:e23504. doi:10.4161/jkst.23504

144. Gil MP, Ploquin MJY, Watford WT, Lee SH, Kim K, Wang X, et al. Regulating type 1 IFN effects in CD8 T cells during viral infections: changing STAT4 and STAT1 expression for function. Blood (2012) 120:3718-28. doi:10.1182/ blood-2012-05-428672

145. Nguyen KB, Watford WT, Salomon R, Hofmann SR, Pien GC, Morinobu A, et al. Critical role for STAT4 activation by type 1 interferons in the interferon-gamma response to viral infection. Science (2002) 297:2063-6. doi:10.1126/science. 1074900
146. Schneider WM, Chevillotte MD, Rice CM. Interferon-stimulated genes: a complex web of host defenses. Annu Rev Immunol (2014) 32:513-45. doi:10.1146/annurev-immunol-032713-120231

147. Zitvogel L, Galluzzi L, Kepp O, Smyth MJ, Kroemer G. Type I interferons in anticancer immunity. Nat Rev Immunol (2015) 15:405-14. doi:10.1038/ nri3845

148. Tough DF. Modulation of T-cell function by type I interferon. Immunol Cell Biol (2012) 90:492-7. doi:10.1038/icb.2012.7

149. Santini SM, Lapenta C, Logozzi M, Parlato S, Spada M, Di Pucchio T, et al. Type I interferon as a powerful adjuvant for monocyte-derived dendritic cell development and activity in vitro and in Hu-PBL-SCID mice. J Exp Med (2000) 191:1777-88. doi:10.1084/jem.191.10.1777

150. Paquette RL, Hsu NC, Kiertscher SM, Park AN, Tran L, Roth MD, et al. Interferon-alpha and granulocyte-macrophage colony-stimulating factor differentiate peripheral blood monocytes into potent antigen-presenting cells. J Leukoc Biol (1998) 64:358-67.

151. Lee PK, Chang CJ, Lin CM. Lipopolysaccharide preferentially induces 4-1BB ligand expression on human monocyte-derived dendritic cells. Immunol Lett (2003) 90:215-21. doi:10.1016/j.imlet.2003.08.002

152. Rouzaut A, Garasa S, Teijeira A, González I, Martinez-Forero I, Suarez N, et al. Dendritic cells adhere to and transmigrate across lymphatic endothelium in response to IFN- $\alpha$. Eur J Immunol (2010) 40:3054-63. doi:10.1002/ eji.201040523

153. Padovan E, Spagnoli GC, Ferrantini M, Heberer M. IFN-alpha2a induces IP-10/CXCL10 and MIG/CXCL9 production in monocyte-derived dendritic cells and enhances their capacity to attract and stimulate CD8+ effector T cells. J Leukoc Biol (2002) 71:669-76.

154. Parlato S, Santini SM, Lapenta C, Di Pucchio T, Logozzi M, Spada M, et al. Expression of CCR-7, MIP-3beta, and Th-1 chemokines in type I IFNinduced monocyte-derived dendritic cells: importance for the rapid acquisition of potent migratory and functional activities. Blood (2001) 98:3022-9. doi:10.1182/blood.V98.10.3022

155. Wolf E, Spencer KM, Cudworth AG. The genetic susceptibility to type 1 (insulin-dependent) diabetes: analysis of the HLA-DR association. Diabetologia (1983) 24:224-30. doi:10.1007/BF00282704

156. Hanafusa T, Pujol-Borrell R, Chiovato L, Russell RC, Doniach D, Bottazzo GF. Aberrant expression of HLA-DR antigen on thyrocytes in Graves' disease: relevance for autoimmunity. Lancet (1983) 2:1111-5. doi:10.1016/S0140-6736(83)90628-1

157. Pujol-Borrell R, Hanafusa T, Chiovato L, Bottazzo GF. Lectin-induced expression of DR antigen on human cultured follicular thyroid cells. Nature (1983) 304:71-3. doi:10.1038/304071a0

158. Unanue ER. Antigen-presenting function of the macrophage. Annu Rev Immunol (1984) 2:395-428. doi:10.1146/annurev.iy.02.040184.002143

159. Foulis AK, Farquharson MA, Hardman R. Aberrant expression of class II major histocompatibility complex molecules by B cells and hyperexpression of class I major histocompatibility complex molecules by insulin containing islets in type 1 (insulin-dependent) diabetes mellitus. Diabetologia (1987) 30:333-43. doi:10.1007/BF00299027

160. Richardson SJ, Willcox A, Bone AJ, Morgan NG, Foulis AK. Immunopathology of the human pancreas in type-I diabetes. Semin Immunopathol (2011) 33:9-21. doi:10.1007/s00281-010-0205-0

161. Foulis AK. The pathology of the endocrine pancreas in type 1 (insulindependent) diabetes mellitus. APMIS (1996) 104:161-7. doi:10.1111/ j.1699-0463.1996.tb00702.x

162. Rodriguez-Calvo T, Suwandi JS, Amirian N, Zapardiel-Gonzalo J, Anquetil F, Sabouri S, et al. Heterogeneity and lobularity of pancreatic pathology in type 1 diabetes during the prediabetic phase. J Histochem Cytochem (2015) 63:626-36. doi:10.1369/0022155415576543

163. Ziegler AG, Rewers M, Simell O, Simell T, Lempainen J, Steck A, et al. Seroconversion to multiple islet autoantibodies and risk of progression to diabetes in children. JAMA (2013) 309:2473-9. doi:10.1001/jama.2013.6285

164. Chehadeh W, Weill J, Vantyghem MC, Alm G, Lefèbvre J, Wattré P, et al. Increased level of interferon-alpha in blood of patients with insulindependent diabetes mellitus: relationship with coxsackievirus B infection. J Infect Dis (2000) 181:1929-39. doi:10.1086/315516

165. Xia CQ, Peng R, Chernatynskaya AV, Yuan L, Carter C, Valentine J, et al. Increased IFN-alpha-producing plasmacytoid dendritic cells (pDCs) in human Th1-mediated type 1 diabetes: pDCs augment Th1 responses 
through IFN-alpha production. J Immunol (2014) 193:1024-34. doi:10.4049/ jimmunol.1303230

166. Taylor JL, Grossberg SE. Recent progress in interferon research: molecular mechanisms of regulation, action, and virus circumvention. Virus Res (1990) 15:1-25. doi:10.1016/0168-1702(90)90010-9

167. Wills RJ. Clinical pharmacokinetics of interferons. Clin Pharmacokinet (1990) 19:390-9. doi:10.2165/00003088-199019050-00003

168. Bonnevie-Nielsen V, Larsen ML, Frifelt JJ, Michelsen B, Lernmark A. Association of IDDM and attenuated response of 2,5'-oligoadenylate synthetase to yellow fever vaccine. Diabetes (1989) 38:1636-42. doi:10.2337/ diabetes.38.12.1636

169. Toms GC, Baker P, Boucher BJ. The production of immunoreactive alpha- and gamma-interferon by circulating mononuclear cells in type 1 diabetes. Diabet Med (1991) 8:547-50. doi:10.1111/j.1464-5491.1991. tb01649.x

170. Fabris P, Floreani A, Tositti G, Vergani D, De Lalla F, Betterle C. Type 1 diabetes mellitus in patients with chronic hepatitis $\mathrm{C}$ before and after interferon therapy. Aliment Pharmacol Ther (2003) 18:549-58. doi:10.1046/j. 1365-2036.2003.01681.x

171. Tai TY, Lu JY, Chen CL, Lai MY, Chen PJ, Kao JH, et al. Interferon-alpha reduces insulin resistance and beta-cell secretion in responders among patients with chronic hepatitis B and C. JEndocrinol (2003) 178:457-65. doi:10.1677/joe.0.1780457

172. Nemesanszky E, Pusztay M, Csepregi A. Effects of interferon treatment on the glucose metabolism of patients with chronic hepatitis C. Eur J Intern Med (2000) 11:151-5. doi:10.1016/S0953-6205(00)00080-7

173. Nakhooda AF, Like AA, Chappel CI, Murray FT, Marliss EB. The spontaneously diabetic Wistar rat. Metabolic and morphologic studies. Diabetes (1977) 26:100-12. doi:10.2337/diabetes.26.2.100

174. Colle E, Guttmann RD, Seemayer T. Spontaneous diabetes mellitus syndrome in the rat. I. Association with the major histocompatibility complex. J Exp Med (1981) 154:1237-42. doi:10.1084/jem.154.4.1237

175. Ewel CH, Sobel DO, Zeligs BJ, Bellanti JA. Poly I:C accelerates development of diabetes mellitus in diabetes-prone BB rat. Diabetes (1992) 41:1016-21. doi:10.2337/diabetes.41.8.1016

176. Sobel DO, Ewel CH, Zeligs B, Abbassi V, Rossio J, Bellanti JA. Poly I:C induction of alpha-interferon in the diabetes-prone BB and normal Wistar rats. Dose-response relationships. Diabetes (1994) 43:518-22. doi:10.2337/ diab.43.4.518

177. Huang X, Hultgren B, Dybdal N, Stewart TA. Islet expression of interferonalpha precedes diabetes in both the BB rat and streptozotocin-treated mice. Immunity (1994) 1:469-78. doi:10.1016/1074-7613(94)90089-2

178. Makino S, Kunimoto K, Muraoka Y, Mizushima Y, Katagiri K, Tochino Y. Breeding of a non-obese, diabetic strain of mice. Jikken Dobutsu (1980) 29:1-13.

179. O'Brien BA, Geng X, Orteu CH, Huang Y, Ghoreishi M, Zhang Y, et al. A deficiency in the in vivo clearance of apoptotic cells is a feature of the NOD mouse. J Autoimmun (2006) 26:104-15. doi:10.1016/j.jaut.2005.11.006

180. Swiecki M, Colonna M. The multifaceted biology of plasmacytoid dendritic cells. Nat Rev Immunol (2015) 15:471-85. doi:10.1038/nri3865

181. Lincez PJ, Shanina I, Horwitz MS. Reduced expression of the MDA5 Gene IFIH1 prevents autoimmune diabetes. Diabetes (2015) 64:2184-93. doi: $10.2337 / \mathrm{db} 14-1223$

182. Lee AS, Ghoreishi M, Cheng WK, Chang TY, Zhang YQ, Dutz JP. Toll-like receptor 7 stimulation promotes autoimmune diabetes in the NOD mouse. Diabetologia (2011) 54:1407-16. doi:10.1007/s00125-011-2083-y

183. Zhang Y, Lee AS, Shameli A, Geng X, Finegood D, Santamaria P, et al. TLR9 blockade inhibits activation of diabetogenic CD8+ T cells and delays autoimmune diabetes. J Immunol (2010) 184:5645-53. doi:10.4049/ jimmunol.0901814

184. Li Q, McDevitt HO. The role of interferon alpha in initiation of type I diabetes in the NOD mouse. Clin Immunol (2011) 140:3-7. doi:10.1016/j. clim.2011.04.010

185. Quah HS, Miranda-Hernandez S, Khoo A, Harding A, Fynch S, Elkerbout L, et al. Deficiency in type I interferon signaling prevents the early interferon-induced gene signature in pancreatic islets but not type 1 diabetes in NOD mice. Diabetes (2014) 63:1032-40. doi:10.2337/db13-1210

186. Mordes JP, Guberski DL, Leif JH, Woda BA, Flanagan JF, Greiner DL, et al. LEW.1WR1 rats develop autoimmune diabetes spontaneously and in response to environmental perturbation. Diabetes (2005) 54:2727-33. doi:10.2337/diabetes.54.9.2727

187. Qaisar N, Lin S, Ryan G, Yang C, Oikemus SR, Brodsky MH, et al. A critical role for the type I interferon receptor in virus-induced autoimmune diabetes in rats. Diabetes (2017) 66:145-57. doi:10.2337/db16-0462

188. Vassileva G, Chen SC, Zeng M, Abbondanzo S, Jensen K, Gorman D, et al. Expression of a novel murine type I IFN in the pancreatic islets induces diabetes in mice. J Immunol (2003) 170:5748-55. doi:10.4049/jimmunol. 170.11 .5748

189. Alba A, Puertas MC, Carrillo J, Planas R, Ampudia R, Pastor X, et al. IFN beta accelerates autoimmune type 1 diabetes in nonobese diabetic mice and breaks the tolerance to beta cells in nondiabetes-prone mice. JImmunol (2004) 173:6667-75. doi:10.4049/jimmunol.173.11.6667

190. Somoza N, Vargas F, Roura-Mir C, Vives-Pi M, Fernandez-Figueras MT, Ariza A, et al. Pancreas in recent onset insulin-dependent diabetes mellitus. Changes in HLA, adhesion molecules and autoantigens, restricted $\mathrm{T}$ cell receptor $\mathrm{V}$ beta usage, and cytokine profile. J Immunol (1994) 153:1360-77.

191. Roep BO, Kleijwegt FS, van Halteren AG, Bonato V, Boggi U, Vendrame F, et al. Islet inflammation and CXCL10 in recent-onset type 1 diabetes. Clin Exp Immunol (2010) 159:338-43. doi:10.1111/j.1365-2249.2009.04087.x

192. Uno S, Imagawa A, Saisho K, Okita K, Iwahashi H, Hanafusa T, et al. Expression of chemokines, CXC chemokine ligand 10 (CXCL10) and CXCR3 in the inflamed islets of patients with recent-onset autoimmune type 1 diabetes. Endocr J (2010) 57:991-6. doi:10.1507/endocri.K10E-076

193. Newby B, Annamali M, Brusko T, Gerling I, Mathews C. Type 1 Interferons Create a Virulent Islet Microenvironment. San Diego, CA: American Diabetes Association (ADA) 77th Scientific Sessions (2017).

194. Freudenburg W, Gautam M, Chakraborty P, James J, Richards J, Salvatori AS, et al. Reduction in ATP levels triggers immunoproteasome activation by the $11 \mathrm{~S}$ (PA28) regulator during early antiviral response mediated by IFNbeta in mouse pancreatic beta-cells. PLoS One (2013) 8:e52408. doi:10.1371/journal. pone. 0052408

195. Seifert U, Bialy LP, Ebstein F, Bech-Otschir D, Voigt A, Schröter F, et al. Immunoproteasomes preserve protein homeostasis upon interferon-induced oxidative stress. Cell (2010) 142:613-24. doi:10.1016/j.cell.2010.07.036

196. Neefjes J, Jongsma ML, Paul P, Bakke O. Towards a systems understanding of MHC class I and MHC class II antigen presentation. Nat Rev Immunol (2011) 11:823-36. doi:10.1038/nri3084

197. Eizirik DL, Cardozo AK, Cnop M. The role for endoplasmic reticulum stress in diabetes mellitus. Endocr Rev (2008) 29:42-61. doi:10.1210/er. 2007-0015

198. Eizirik DL, Miani M, Cardozo AK. Signalling danger: endoplasmic reticulum stress and the unfolded protein response in pancreatic islet inflammation. Diabetologia (2013) 56:234-41. doi:10.1007/s00125-012-2762-3

199. Granados DP, Tanguay PL, Hardy MP, Caron E, de Verteuil D, Meloche S, et al. ER stress affects processing of MHC class I-associated peptides. BMC Immunol (2009) 10:10. doi:10.1186/1471-2172-10-10

200. Ulianich L, Terrazzano G, Annunziatella M, Ruggiero G, Beguinot F, Di Jeso B. ER stress impairs MHC class I surface expression and increases susceptibility of thyroid cells to NK-mediated cytotoxicity. Biochim Biophys Acta (2011) 1812:431-8. doi:10.1016/j.bbadis.2010.12.013

201. de Almeida SF, Fleming JV, Azevedo JE, Carmo-Fonseca M, de Sousa M. Stimulation of an unfolded protein response impairs MHC class I expression. J Immunol (2007) 178:3612-9. doi:10.4049/jimmunol.178.6.3612

202. Zanone MM, Favaro E, Camussi G. From endothelial to beta cells: insights into pancreatic islet microendothelium. Curr Diabetes Rev (2008) 4:1-9. doi:10.2174/157339908783502415

203. Itoh N, Hanafusa T, Miyazaki A, Miyagawa J, Yamagata K, Yamamoto K, et al. Mononuclear cell infiltration and its relation to the expression of major histocompatibility complex antigens and adhesion molecules in pancreas biopsy specimens from newly diagnosed insulin-dependent diabetes mellitus patients. J Clin Invest (1993) 92:2313-22. doi:10.1172/JCI116835

204. Chakrabarti D, Huang X, Beck J, Henrich J, McFarland N, James RF, et al. Control of islet intercellular adhesion molecule-1 expression by interferonalpha and hypoxia. Diabetes (1996) 45:1336-43. doi:10.2337/diab.45.10.1336

205. Savinov AY, Wong FS, Stonebraker AC, Chervonsky AV. Presentation of antigen by endothelial cells and chemoattraction are required for homing of insulin-specific CD8+ T cells. J Exp Med (2003) 197:643-56. doi:10.1084/ jem.20021378 
206. Zanone MM, Favaro E, Ferioli E, Huang GC, Klein NJ, Perin PC, et al. Human pancreatic islet endothelial cells express coxsackievirus and adenovirus receptor and are activated by coxsackie B virus infection. FASEB J (2007) 21:3308-17. doi:10.1096/fj.06-7905com

207. Hogan MF, Hull RL. The islet endothelial cell: a novel contributor to beta cell secretory dysfunction in diabetes. Diabetologia (2017) 60:952-9. doi:10.1007/ s00125-017-4272-9

208. Longhi MP, Trumpfheller C, Idoyaga J, Caskey M, Matos I, Kluger C, et al. Dendritic cells require a systemic type I interferon response to mature and induce CD4+ Th1 immunity with poly IC as adjuvant. J Exp Med (2009) 206:1589-602. doi:10.1084/jem.20090247

209. Pantel A, Teixeira A, Haddad E, Wood EG, Steinman RM, Longhi MP. Direct type I IFN but not MDA5/TLR3 activation of dendritic cells is required for maturation and metabolic shift to glycolysis after poly IC stimulation. PLoS Biol (2014) 12:e1001759. doi:10.1371/journal.pbio.1001759

Conflict of Interest Statement: The authors declare that the research was conducted in the absence of any commercial or financial relationships that could be construed as a potential conflict of interest.

Copyright (c) 2017 Newby and Mathews. This is an open-access article distributed under the terms of the Creative Commons Attribution License (CC BY). The use, distribution or reproduction in other forums is permitted, provided the original author(s) or licensor are credited and that the original publication in this journal is cited, in accordance with accepted academic practice. No use, distribution or reproduction is permitted which does not comply with these terms. 